\title{
CAN RELIGION INSURE AGAINST AGGREGATE SHOCKS TO HAPPINESS? THE CASE OF TRANSITION COUNTRIES
}

\author{
Olga Popova
}
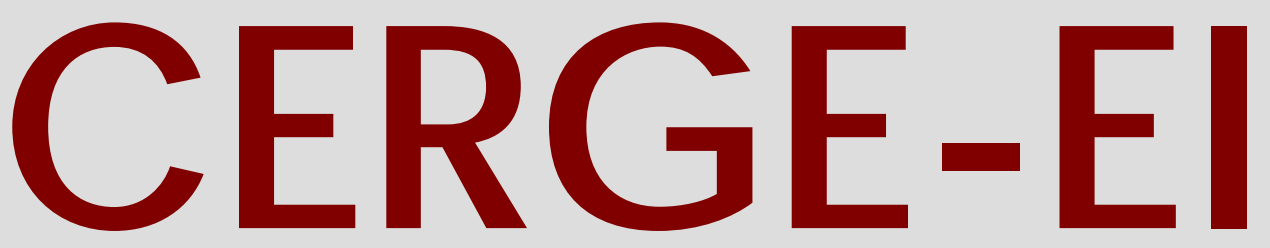

Charles University Centerfor Ec onomic Research and Graduate Education Academy of Sciences of the Czech Republic Ec onomic s Institute 


\section{Working Paper Series $\quad 425$ (ISSN 1211-3298)}

\section{Can Religion Insure against Aggregate Shocks to Happiness? The Case of Transition Countries}

Olga Popova

CERGE-EI

Prague, October 2010 
ISBN 978-80-7343-224-9 (Univerzita Karlova. Centrum pro ekonomický výzkum a doktorské studium)

ISBN 978-80-7344-214-9 (Národohospodářský ústav AV ČR, v.v.i.) 


\title{
Can Religion Insure against Aggregate Shocks to Happiness? The Case of Transition Countries*
}

\author{
Olga Popova ${ }^{\dagger}$
}

\begin{abstract}
This paper focuses on the effects of reforms and religion on happiness in transition economies. Previous literature suggests that religiousness insures happiness against individual stressful life events, such as unemployment, disability, or marital separation. I estimate an econometric model to study if religion also insures against aggregate shocks to happiness, such as reforms and various changes in political, economic, and social life. The model accounts for the endogeneity of religion and analyzes the effects of religion on life satisfaction, and perceptions of the current economic and political situation in transition countries.
\end{abstract}

\begin{abstract}
Abstrakt
Tato práce se zaměřuje na dopady reforem a náboženství na štěstí v tranzitivních ekonomikách. Předchozí literatura naznačuje, že religiozita pojištuje štěstí proti jednotlivým stresujícím životním událostem, jako je nezaměstnanost, zdravotní postižení nebo rozpad manželství. Navrhuji ekonometrický model pro studium otázky, zda náboženství také pojišt'uje proti agregátním šokům ve štěstí, jako jsou reformy a různé změny $\mathrm{v}$ politickém, hospodářském a společenském životě. Tento model bere v ůvahu endogenitu náboženství a analyzuje vliv náboženství na životní spokojenost a vnímání současné ekonomické a politické situaci v tranzitivních zemích.
\end{abstract}

Keywords: happiness, life satisfaction, religion, reforms, transition JEL Classification: C21, I31, P20, Z12

${ }^{*}$ I would like to thank Lubomir Lizal, Jan Kmenta and Stepan Jurajda for valuable comments and helpful suggestions. I am also thankful to Andrew Clark, Gerd Groezinger, Byeongju Jeong, Tatiana Kosyaeva, Gerard Roland (in alphabetic order) and participants at the conference Happiness and Relational Goods: Well-being and Interpersonal Relations in the Economic Sphere (Venice) for the comments on earlier drafts of this paper. I am also thankful to Sarah Peck for English editing. All errors remaining in this text are the responsibility of the author.

${ }^{\dagger}$ CERGE-EI is a joint workplace of the Center for Economic Research and Graduate Education, Charles University, Prague, and the Economics Institute of the Academy of Sciences of the Czech Republic. Address: CERGE-EI, P.O. Box 882, Politickych veznu 7, Prague 1, 111 21, Czech Republic. E-mail: Olga.Popova@cerge-ei.cz. 


\section{Introduction}

Although transition economies demonstrate stable economic growth and progress in the market reform process (EBRD, 2006), the adaptation of people to the transition period and to the new conditions of a market economy is not yet over. People from transition economies still, in fact, report lower levels of life satisfaction than people from developed market economies. ${ }^{1}$ Moreover, life satisfaction in transition countries is not just lower than in developed economies, but it decreased during the transition period (see Sanfey and Teksoz, 2007; Easterlin, 2009). ${ }^{2}$

According to existing literature, socio-demographic and economic determinants of subjective well-being are typically the same for transition as for developed countries: among other determinants, happiness is found to be U-shaped in age; women and wealthier, educated, employed, married people are likely to be happier. ${ }^{3}$ The reasons for a decrease in life satisfaction during the transition period have not been studied extensively in previous literature. Existing studies relate this decrease in life satisfaction with high inflation, income inequality and poor governance quality in transition countries (Sanfey and Teksoz, 2007), the fall in real GDP per capita during transition (Easterlin, 2009), high macroeconomic instability, insufficient provision of public goods and human capital depreciation in transition countries (Guriev and Zhuravskaya, 2009). The research on developed countries underlines that life satisfaction is negatively affected by economic instability. For example, high unemployment, income inequality and inflation tend to have negative effect on life satisfaction (see Clark and Oswald, 1994; Di Tella et al., 2001, among others). In

\footnotetext{
${ }^{1}$ According to World Values Survey and World Database of Happiness (see Table 1).

${ }^{2}$ The terms "life satisfaction" and "happiness" are used in the paper interchangebly. Throughout the paper we refer to the definition of happiness as given by Veenhoven in the World Database of Happiness: "happiness is the degree to which an individual judges the overall quality of her/his life as-a-whole favorably" (http://worlddatabaseofhappiness.eur.nl; Bibliography, Ch.2).

${ }^{3}$ The determinants of happiness during economic transition in a cross-country setting are explored by Hayo and Seifert (2003), Hayo (2007), Sanfey and Teksoz (2007), Easterlin (2009), and Guriev and Zhuravskaya (2009). The determinants of happiness to be similar to developed countries are found by studies that use a single transition country for the analysis (for instance, Russia by Veenhoven, 2001 and Graham et al., 2004; Kyrgyzstan by Namazie and Sanfey, 2001; Hungary in Lelkes, 2006; Kazakhstan by Kalyuzhnova and Kambhampati, 2008; among others).
} 
this research I argue that the market reform process and subsequent changes and instability in the economic and social situation during transition are likely to be painful, negatively affecting life satisfaction. Such effects of the transition period reforms on life satisfaction could be an additional explanation for the decrease in happiness during transition. I relate decrease in happiness with the effects of major reforms in the transition period, such as privatization, price liberalization, enterprise restructuring and others.

Another contribution of this paper is related to studying the so-called insurance effect of religion in the case of aggregate shocks. As highlighted in previous research, personal religiousness may insure life satisfaction against declines during stressful idiosyncratic life events. These idiosyncratic shocks such as changes in individual income, employment or social status decrease a person's happiness, although religious people are likely to recover from such shocks faster because of different values, attitudes, and norms in their life (see Clark and Lelkes, 2006; Dehejia et al., 2007, among others). In this research I consider reforms during transition as aggregate shocks to happiness and study the insurance effect of religion in relation to aggregate shocks. To overcome the problem of potential endogeneity in the relationship between happiness and religion, I propose to use historical religious propensity as an instrumental variable for religion.

Different responses of religious and non-religious people to aggregate happiness shocks may imply their different attitudes toward reforms, and, thus, different speed of reform implementation in countries with different religious propensity. The analysis of this paper sheds light on the differences in happiness levels between developed market economies and transition countries, and differences in the speed of reform implementation in transition countries. Life satisfaction, perception of the current economic situation, and perception of the current political situation are used as dependent variables in three model specifications. The data used in this study are taken from the Life in Transition Survey (LiTS) of EBRD, EBRD Transition Indi- 
cators, and World Christian Database.

As the results of this paper indicate, major reforms in transition affected individual life satisfaction and perceptions of the economic and political situation. These effects were positive for some reforms and negative for others. Religious people are likely to be satisfied with their life and the economic and political situation. Religious people are also likely to suffer less from the negative effects of reforms; that is, religion insures against aggregate shocks to happiness. Other findings of the paper suggest that life satisfaction and perceptions of economic and political situation are U-shaped in age, more educated people are likely to be happier and satisfied with the economic and political situation, the employed are satisfied more than the unemployed, happiness increases with households size and marriage, and divorce decreases happiness.

The rest of the paper is organized as follows. The next section presents a review of relevant literature. In further sections I describe the methodology and identification strategy, data and discuss estimation results. The final section concludes.

\section{Literature}

For a long time economists have not paid attention to self-reported individual wellbeing, leaving this area for philosophical, psychological, and sociological research. Data on self-reported happiness were used for the first time in economic research by Easterlin $(1974,1995)$ who investigated the relationship between income, economic growth, and well-being. The economics of happiness as a discipline started its intensive development after the paper by Kahnemann (1997), who underlined the usefulness of data on self-reported happiness for measuring individual experienced utility. Nowadays, happiness data are widely used in economic empirical research as a measure of individual utility, which was previously investigated mostly theoretically. 
To date, different aspects of life satisfaction and its determinants in developed countries have been investigated within economics. The most prominent research analyzes happiness and relative income, income inequality, religiousness, unemployment, the role of democracy, crime, health, education, urbanization, inflation, GDP and GDP growth; climate changes and environmental pollution. ${ }^{4}$

The first theoretical model of religious participation is by Azzi and Ehrenberg (1975), who construct a multi-period utility maximization problem where a household (both wife and husband) decides about work, leisure, and a non-market activity such as participation in religious activities. The authors also discuss the determinants of religious participation and reasons for becoming religious. First, as the authors point out, an individual believes that participation in religious activities today brings him/her additional after-life satisfaction. Second, an individual may like socializing with people who attend religious organizations. Religious participation in this case brings him/her additional life satisfaction today. Third, an individual may attend a religious organization because of social pressure from the community in which he/she lives. In this case it is not determined what effect religious participation has on today's happiness.

After a theoretical paper by Azzi and Ehrenberg (1975), researchers started empirical investigation of the link between happiness and religiousness. One of the earliest empirical studies is Ellison (1991) who tests different aspects of religious activity. The author finds that the effect of church attendance on happiness is indirect. Church attendance strengthens religious belief which influences happiness directly. Religiousness also decreases the loss in happiness during negative life events. This finding was further tested by scholars (Clark and Lelkes, 2006; Dehejia et al., 207; among others), and Clark and Lelkes (2006 ) defined it as the insurance effect of

\footnotetext{
${ }^{4}$ For details about the mentioned effects, see Alesina et al., 2004; Clark and Oswald, 1994; Di Tella et al, 2001 and 2003; Dynan and Ravina, 2007; Easterlin, 1995 and 2001; Ellison, 1991; Ferreri-Carbonell, 2005; Frey and Stutzer, 2000; Gerdtham and Johannesson, 2001; Hadaway, 1978; Luttmer, 2005; Michalos and Zumbo, 2000; Morawetz et al., 1977; Powdthavee, 2005; Rehdanz and Maddison, 2005; Welsch, 2007; Winkelmann and Winkelmann, 1998, among others.
} 
religiousness. As Clark and Lelkes (2006) argue, religiousness insures against such idiosyncratic life events as unemployment or marital separation, though this insurance effect of religiousness on happiness may differ across different religious denominations. The authors explain the insurance role of religion by arguing that during stressful life events the support that a person receives from a religious organization, or from religious belief itself, is a substitute for social support. Dehejia et al. (2007) discuss the insurance effects of religion further. The authors using US data argue that religious participation, namely contributions to religious organizations and church attendance, partially helps to insure consumption and happiness against changes in individual income. The authors underline that this result has an important policy implication for public social insurance: in regions with high religious participation, people would need public insurance less. Again the insurance effect of religion is found to be effective for idiosyncratic shocks to happiness only.

Recent empirical studies address various aspects of the relationship between religion, happiness and economic indicators. For instance, Guiso et al. (2003) find positive correlation between religiousness and attitudes towards economic growth. Mookerjee and Beron (2005), using data on happiness across 60 countries (both developed and developing), find that greater religious diversity in a country decreases average happiness in a country. It implies that mono-religious countries report on average greater happiness levels than poli-religious countries.

One of the studies on the relationship between religion and happiness in transition is Lelkes (2006) who uses data from a Hungarian survey. As the author argues, more economic freedom as the result of transition increases the happiness of entrepreneurs, but more freedom in ideology does not affect the happiness of religious people. Another finding of this paper is that religious people are, on average, happier than non-religious, and they are less affected by changes in their individual income because income is not among the main sources of their happiness. Clark and Lelkes (2009), while discussing the relationship between religiosity and life sat- 
isfaction, take into account both individual religiosity (churchgoing, praying, selfidentification with some religious denomination) and average religiosity in a region (percentage of religious people in a region). The authors find positive correlation not only between individual religiosity and individual life satisfaction, but also between average religiosity in a region and individual life satisfaction. As Clark and Lelkes (2009) point out, both religious people and atheists are likely to be happier in more religious regions.

There exist, however, a potential endogeneity problem in the relationship between happiness and religion that has not yet been closely investigated in the literature. Indeed, since among the reasons to become religious are socializing and support as well as the belief in after-life satisfaction (as pointed out by Azzi and Ehrenberg, 1975), some time constant personal unobservable characteristics, for instance, optimism or pessimism, love for socializing activities, trustfulness, and others that do matter for personal happiness are likely to be correlated with personal religiousness too. There is also a potential temporal endogeneity: while facing tragic life events that reduce individual happiness, people are likely to become religious so to maintain themselves during these events. There are few studies that address the religion endogeneity problem in a context different from studying the relationship between happiness and religion. For instance, Gruber (2005) studies the relationship between religious participation and various economic and social indicators, such as education, income, disability, marriage, and divorce, and uses the ancestral density in the area as an instrument for religious density, which is the number of people in a given area who share the same religious denomination with the respondent. This instrument predicts religious density well: predicted religious density is strongly correlated with religious participation. As such this instrument is valid for the estimation of the effects of religious participation on economic outcomes. Recently Bettendorf and Dijkgraaf (2010) have also employed a simultaneous equations approach to correct for endogeneity of religion in studying the effect of religion on 
income. The potential endogeneity problem in the relationship between happiness and religion has been discussed in recent studies, for instance, by Dehejia et al., 2007; Clark and Lelkes, 2009, but not yet addressed in research.

This paper contributes to existing literature in several ways. First, I use an instrumental variable approach to overcome the endogeneity problem in a relationship between happiness and religion. Second, I study the effects of aggregate shocks, such as various reforms, on happiness and the insurance effect of religion in relation to aggregate shocks. As reviewed above, to date the insurance effect of religion has been studied in previous literature in relation to idiosyncratic shocks only. Using the data from transition countries as a special laboratory for studying both idiosyncratic and aggregate shocks to happiness, I also further investigate the determinants of happiness in transition countries and analyze not only the relationship between religiousness and life satisfaction, but also between religiousness and perceptions of the current economic and political situation.

\section{Methodological Framework}

\subsection{The Features of Subjective Data}

The analysis of previous research underlines several potential econometric problems we should be aware of while doing this research. Some scholars doubt the use of subjective data for analysis because of possible measurement errors and, thus, biased estimates. Frey and Stutzer (2002a,b) suggest the following main criteria for happiness data that should be used in research: reliability, validity, consistency, and possibility of comparisons across nations. Reliability stands for stable correlation between different measurements of happiness. As it was shown by previous studies, different measures of happiness (life satisfaction) are well-correlated with each

other (Di Tella et al., 2003; Blanchflower and Oswald, 2004; Konow and Earley, 2007). Self-reported subjective well-being very closely approximates individuals' ex- 
perienced utility (Kahnemann, 1997). That is, happiness measures are valid because a person is able to identify and compare his or her own happiness without errors. Consistency in happiness implies that not only does a person judge him/herself as happy, but social interactions confirm it. Happiness can be compared across nations (Di Tella and MacCulloch, 2006). Previous research have shown that all these criteria are satisfied for the self-reported data on happiness (for review and details, see Frey and Stutzer, 2002a, 2002b).

Happiness and life satisfaction is usually assessed by the following types of questions: 'Taking all things together, would you say you are very happy, quite happy, not very happy, or not at all happy?'; 'All things considered, how satisfied are you with your life as a whole these days on the ten-point scale: $1=$ dissatisfied, and 10 = satisfied; percent 'satisfied'. Thus, true individual happiness is not observed, it is a latent variable. Instead, we observe a discrete categorical variable which is measured on a ranking scale. For such cases, ordered probit or ordered logit estimation techniques are applied (Maddala, 1983). In the LiTS data that are used for this research, the question about happiness is as follows: 'To what extent do you agree with the following statement: All things considered, I am satisfied with my life now, Strongly disagree $=1$, Disagree $=2$, Neither disagree nor agree $=3$, Agree $=4$, Strongly agree $=5$ '.

The other concern is that happiness can not be compared across individuals because everybody is different and judges his or her own happiness according to his or her own valuation scale (for instance, 8 out of 10 points on a happiness scale for one individual may have a different value for another individual). However, most happiness studies, including this research, tend to investigate various determinants of happiness but not the absolute value of individual happiness. For such a purpose, as Frey and Stutzer (2002b) point out, self-reported data on individual happiness are suitable. 


\subsection{The Model}

In this research I am interested in the effects of reforms and religion on happiness and perceptions of the economic and political situation. The system of structural equations in which happiness and religion are considered as latent variables is formulated similarly to Bettendorf and Dijkgraaf (2010). In contrast to Bettendorf and Dijkgraaf (2010), I include happiness, not income, as one of the endogenous variables. The resulting system of structural equations expressed using the matrix notation (as in Kmenta, 1997) is

$$
\mathbf{B y}_{i t c}+\Gamma \mathbf{x}_{i t c}=\mathbf{u}_{i t c}
$$

where subscript $i$ stands for individual, subscript $t$ stands for time, and subscript $c$ stands for country. B is a $G \times G$ matrix of coefficients on endogenous variables; $\mathbf{y}_{i t c}$ is a $G \times 1$ vector of endogenous variables; $\boldsymbol{\Gamma}$ is a $G \times K$ matrix of coefficients on exogenous variables; $\mathbf{x}_{i t c}$ is a $K \times 1$ vector of exogenous variables; and $\mathbf{u}_{i t c}$ is a $G \times 1$ vector of stochastic disturbances. A detailed representation of the system is included in the Appendix. There are $G=11$ endogenous variables and $K=34$ exogenous variables. The vector $\mathbf{y}_{\text {itc }}$ includes happiness $s_{i t c}$ which is self-reported individual life satisfaction; religion ${ }_{i}$ which is self-reported individual religiousness; and 9 interaction terms religion $_{i} \times$ reform $_{t c}$. The vector $\mathbf{x}_{i t c}$ includes 9 variables

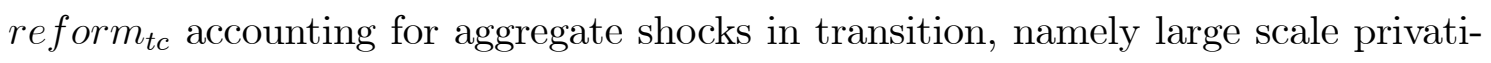
zation, small scale privatization, enterprise restructuring, price liberalization, trade and foreign exchange system reform, competition policy reform, banking reform and interest rate liberalization, securities markets and non-bank financial institutions,

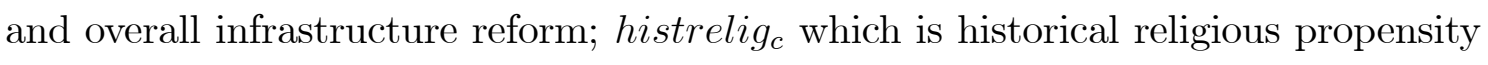
in country $c$; 9 interaction terms histrelig $g_{c} \times$ reform tc $_{c}$; and observable individual socio-economic characteristics, such as age, gender, education, marital and employment status, etc.

True variable happiness ${ }_{i t c}^{*}$ is latent $\underset{10}{\text { and }}$ its ordered alternatives are observed: 
with low happiness ${ }_{i t c}^{*}$ a person is not satisfied with life; with happiness $s_{i t c}^{*}>\mu_{1}$ a person is more satisfied with life; with happiness $s_{i t c}^{*}>\mu_{2}$ a person is even more satisfied with life, and so on. Thresholds $\mu_{j}$ are increasing and unknown:

$$
\text { happiness }_{i t c}=j \text { if } \mu_{j-1}<\text { happiness }_{i t c}^{*} \leq \mu_{j} ; \mu_{0}=-\infty \text { and } \mu_{m}=\infty, j=1 . . J
$$

The observed choice of being religious, religion $_{i}$, is a discrete variable, while true religiousness, religion ${ }_{i}^{*}$, is latent:

$$
\text { religion }_{i}=\left\{\begin{array}{c}
1 \text { if } \text { religion }_{i}^{*}>0 \\
0, \text { otherwise }
\end{array}\right.
$$

To study the direct effects of reforms and religion, I include variables reform $m_{t c}$ and religion $i$ into the equation for happiness. The interaction terms between

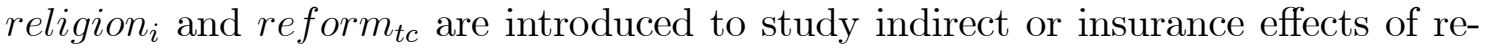
ligion and test whether religion insures individuals against aggregate shocks. This approach is similar to the one suggested by Clark and Lelkes (2006) and Dehejia et al. (2007) for studying the insurance effect of religion in the case of idiosyncratic shocks. If the direct effect of a particular aggregate shock, i.e., the coefficient on reform tc $_{\text {, }}$ is negative, then a positive sign on the respective interaction term implies an insurance effect of religion; if the direct effect of the event is positive, then, symmetrically, the sign on its interaction term with religion should be negative. Three specifications are used to account for three different dependent variables: life satisfaction, perception of current economic situation, and perception of current political situation.

To receive the system of reduced form equations, we solve the structural form equations for the values of endogenous variables (Kmenta, 1997). The resulting system is

$$
\mathbf{y}_{i t c}=\Pi \mathbf{x}_{i t c}+\boldsymbol{\nu}_{i t c}
$$


where $\Pi$ is a $G \times K$ matrix of reduced form coefficients and $\boldsymbol{\nu}_{i t c}$ is a $G \times 1$ vector of reduced form disturbances.

\subsection{Estimation Strategy}

The estimation of the happiness equation, which is the first one in the system of the structural equation without controlling for the endogeneity of religion $i$ and interaction terms religion $_{i} *$ reform tc $_{\mathbf{c}}$, may result in potentially biased and inconsistent estimators of coefficients on these variables. The main source of this potential bias is in simultaneity and unobserved individual heterogeneity. As found in previous literature, religiousness affects happiness. But there is also a potential temporal effect of happiness on religiousness: unhappy people are likely to become religious, especially during stressful life events. Thus, reverse causality has a negative impact and the estimates without controlling for endogeneity are biased downwards. Some of the individual unobservable time constant characteristics captured by the error term $u_{1 i t c}$ may also bias the estimators due to a correlation with religion ${ }_{i}$ and thus with interaction terms religion $_{i} *$ reform $_{\mathbf{t c}}$. Intuitively, this correlation may be positive (e.g., a more trustful person is likely to be religious) leading to estimators being biased downwards. However, the variety of individual psychological characteristics may affect both religiousness and happiness at the same time with different degrees. These characteristics may also affect differently the propensity to belong to a particular religious denomination. Therefore, the sign of correlation and thus the direction of bias may be ambiguous. For example, it is hard to determine who (pessimists or optimists, less sociable or more sociable persons) are likely to become religious and whether or not these characteristics affect different religious denominations differently.

The approach to the estimation of the model is as follows. First, the Hausman (1978) endogeneity test is performed to check whether religion $i$ and, thus, interaction terms religion $_{i} *$ reform tc $_{t c}$ are indeed endogenous. I separately estimate the 
"reduced form" for religion ${ }_{i}$ and every interaction term religion $_{i} *$ reform $_{t c}$ by regressing it on all exogenous variables, obtain the residuals, and then include the vector of obtained residuals into the happiness equation and test for significance. I perform the test for joint significance of residuals with the null hypothesis that religion and all interaction terms with it are exogenous, and alternative that at least one suspected variable is endogenous. I also separately test the significance of each residual term included into the structural equation. If the coefficients on residuals are significant, then the null hypothesis of respective variable exogeneity is rejected.

To solve the problem of religion $i$ endogeneity, we should have an instrument, that is, an appropriate measure for religiousness that is not person specific. As an instrument for individual religiousness religion $_{i}$, I propose historical religious propensity in a given country, histrelig ${ }_{c}$, which is the number of people of a given religion in a given country at the beginning of the 20th century. As IVs for the interaction terms I use the interaction terms of the mentioned IV for religion $i$ and the variables reform tc $_{\text {c }}$, i.e., histrelig $*$ reform $\mathbf{t c}$. A valid instrument should be correlated with personal religiousness, i.e., $\operatorname{cov}\left(\right.$ religion $_{i}$, histrelig $\left._{c}\right) \neq 0$, but not correlated with unobservable happiness characteristics, i.e., cov(histrelig $\left.g_{c}, u_{1 i t c}\right)=$ 0 .

The historical religious propensity is likely to be correctly excluded from the happiness equation. According to the psychological study by Lyubomirsky et al. (2005), personal happiness depends on genetics, individual activities and life circumstances, including current demographic and environmental factors, life status and personal life history. Thus, current happiness is not altered by the historical environmental characteristics, such as historical religious propensity in our case. Historical presence of religious people in a region is also likely to be uncorrelated with unobservable current individual happiness characteristics. ${ }^{5}$ Since it is not possible to test for IV

\footnotetext{
${ }^{5}$ It could be expected that the repression of religion under communism or people transfers from religious to non-religious regions made formerly religious regions more unhappy. In this case the fall of communism could potentially bring extra happiness to formerly religious regions. Thus, historical religious propensity may not be correctly excluded from equation (1) in this case or be
} 
validity in an exactly identified case (see, e.g., Cameron and Trivedi, 2005), I assume that chosen IVs are valid by construction. As pointed out by Tomka (1994) and Need and Evans (2001), personal religiousness in post-communist countries has been suppressed by communism to a lesser extent than the functioning of religious institutions. Thus, historical and current religious propensity are likely to be correlated and our instruments are not weak. ${ }^{6}$ To insure that instrumental variables are chosen correctly, I also check that partial correlations of chosen instruments and endogenous variables are non-zero and perform the first stage F-test for weak IV as proposed by Stock and Yogo (2005).

Given that proposed instruments are not weak and valid, at the first stage I estimate the system of reduced form equations to get the predicted value of religion $_{i}$, religion $_{i}$ and the predicted values for each of the 9 interaction terms religion $_{i} *$ reform $_{t c}$. At the second stage, I use religion ${ }_{i}$ and all the religion $\hat{f}_{i} *$ reform fo $_{t c}$ to estimate the structural form of happiness equation by ordered logit (as described by, e.g., Cameron and Trivedi, 2005) bootstrapping standard errors to correct them for using religion ${ }_{i}$ and religion $_{i} *$ reform $_{t c}$ instead of religion $i$ and religion $_{i} *$ reform fc $_{\text {. }}$

In a cross-country analysis the variance of the error term is never the same across different countries because of different effects of explanatory variables, i.e., the homoskedasticity assumption fails (Wooldridge, 2002). To account for this, I use heteroskedasticity robust standard errors. Standard errors are also clustered by region to account for possible similarities in characteristics of people living in the same region. It results in 60 clusters according to the number of regions in the data which is large enough (more than 50) to have no inference problem (Donald and

endogenous as is personal religiousness. However, as pointed out by Easterlin (2009), all transition countries experienced a similar decline in happiness after the fall of communism. Therefore, the potential depressive effect of communism on happiness in formerly religious regions and happiness recovery after the fall of communism may be neglected.

${ }^{6}$ As Putnam (1993) shows, trust across Italian regions today is perfectly explained by trust centuries ago. This argument may also explain the correlation between current and historical religious propensity since the propensity to trust and the propensity to be religious are likely to be related to each other. 
Lang, 2007).

First, all the models are estimated without interaction terms, then interaction terms are added. It should be noted, however, that dropping interaction terms out of the model could result in biased and inconsistent estimators due to misspecification. To check the robustness of the results to the choice of estimation method, I redefine the dependent variable into a zero/one (all dissatisfied/all satisfied) scale and estimate the linear probability model (LPM) with the same IVs. ${ }^{7}$

\section{Data}

The main dataset that is used in this research is the Life in Transition Survey (LiTS). It was jointly conducted in 2006 by the EBRD and World Bank and covers all 29 transition countries. ${ }^{8}$ The survey is based on nationally representative samples with 1000 respondents selected randomly from each transition country and contains information on attitudes, values and socio-economic characteristics of respondents. One more advantage of this survey is the possibility to treat it as a panel because the information is collected in such a way that individuals are asked about their past experiences and attitudes, about their life before, throughout, and after the transition. The survey initially contains 29000 observations. I exclude Tajikistan from research since the sample for Tajikistan in LiTS contains 70 percent of Christians which is not consistent with the WCD data on the major denomination in Tajikistan being Islam. I also exclude Turkey from the initial sample due to the unavailability of EBRD transition indicators for this country. Finally, I exclude from the sample

\footnotetext{
${ }^{7}$ Note that the model without interaction terms also has a different interpretation of coefficients on the main effects (Ozer-Balli and Sorensen, 2010). As such, in a correctly specified LPM with interaction terms, the coefficients on the main effects of reforms are the partial derivatives of the respective variable evaluated when religion is equal to zero, while in a model without the interaction terms the partial derivatives are evaluated when religion is equal to its mean.

${ }^{8}$ In line with general classification the transition countries are Albania, Armenia, Azerbaijan, Belarus, Bosnia and Herzegovina, Bulgaria, Croatia, Czech Republic, Estonia, FYR Macedonia, Georgia, Hungary, Kazakhstan, Kyrgyz Republic, Latvia, Lithuania, Moldova, Mongolia, Montenegro, Poland, Romania, Russia, Serbia, Slovak Republic, Slovenia, Tajikistan, Turkey, Ukraine, and Uzbekistan.
} 
observations where a respondent refused to answer the question or where values for major variables are missing (mainly, for the variables that serve as dependent in our specifications). Finally, the result is about 19 to 27 thousand observations, depending on specification and dependent variable used.

The data on historical IV for religion are from the World Christian Database (WCD), which provides statistical information on all world religions. Particularly, the variables of our interest are the adherents of a given religion in a given country in the year 1900, and the adherents of a given religion in a given country in 1900 as a per cent of total population. The data are collected on the basis of church statistics, government censuses, United Nations statistics, and estimates of informed experts and published by Brill, Netherlands.

I also use the EBRD transition indicators as the data on reforms (aggregate shocks) in transition countries. The EBRD transition indicators have the range from 1 to $4.3(4+)$ where a higher index reflects higher progress in the corresponding area of reforms, namely large scale privatization, small scale privatization, enterprise restructuring, price liberalization, trade and foreign exchange system, competition policy, banking reform and interest rate liberalization, securities markets and nonbank financial institutions, and overall infrastructure reform.

All the summary statistics for the data and detailed description of variables used for analysis are presented in Tables 2-4. Table 2 describes all the variables used for the estimation. Dependent variables are life satisfaction, perception of economic situation and perception of political situation. Explanatory variables are a respondent's religion (or its IV, the number of people of a given religion in a given country in 1900), EBRD transition indicators, a respondent's age and age squared divided by 100 , gender, variables for education, number of children, variables accounting for idiosyncratic shocks (adopted children, marriage and divorce during the transition period 1990-2006), household size, household consumption expenditures, and respondent's employment status. Table 3 presents descriptive statistics for the data. 
Table 4 gives the distribution of answers for the dependent variables. For all dependent variables more than 7 percent of respondents answer that they are strongly satisfied with life or the economic and political situation in their country, 27 to 36 percent are satisfied, 15 to 23 percent are neither dissatisfied nor satisfied, 21 to 29 percent are not satisfied, 10 to 20 percent are not satisfied at all. In the case when dependent variables are redefined into a zero/one scale, 41 to 57 percent are satisfied.

\section{$5 \quad$ Results and Discussion}

This section discusses the direct and indirect effects of religion and reforms on happiness, perceptions of the economic and political situation, and the robustness check of obtained results. The main results for all three specifications are presented in Tables 5 to 10. Table 5 presents estimation results when life satisfaction has been used as a dependent variable. Tables 6 and 7 present the results for perceptions of the current economic and political situation as dependent variables, respectively. For each specification we present the estimation results of ordered logit without instruments for religion and interaction terms and ordered logit with instruments to account for endogeneity of religion and interaction terms. As the robustness check, Tables 8 to 10 include the results of three specifications estimated by a linear probability model with and without IVs.

Since the results of endogeneity tests (see Table A1 in the Appendix) reject the exogeneity hypothesis of religion and interaction terms in all three specifications, ordered logit estimation without instruments produces biased and inconsistent results due to the endogeneity problem. Notably, the results of joint endogeneity tests hold for both ordered logit and LPM. For this reason we do not comment much on the estimation results without instruments. According to the results of the first stage F-test, the proposed instruments are also not weak (see Table A2 in the Appendix). 
Thus, the results of the ordered logit and LPM with instruments are unbiased and consistent.

In Tables A3 to A5 in the Appendix the changes in predicted probabilities of different replies to life satisfaction and perceptions questions for different religiousness values are presented.

The positive coefficient's estimates in the ordered logit imply that with an increase in the respective regressor, the probability of the lowest category ("strongly disagree") decreases and the probability of the highest category ("strongly agree") increases. The signs of the ordered logit coefficient's estimates are inconclusive regarding the effects of regressors on the predicted probabilities of middle categories (Greene, 2003; Hayo, 2007). To understand the effects of the explanatory variables on the predicted probabilities of middle categories, I also compute the marginal effects of the explanatory variables. The marginal effects for the ordered logit without controlling for endogeneity of religion and interaction terms are presented in Tables A6a to A8a in the Appendix. The marginal effects for the ordered logit with the use of instruments to control for endogeneity of religion and interaction terms are presented in Tables A6b to A8b in the Appendix.

\subsection{Religion, Reforms and Life Satisfaction: Direct Effects}

The estimation of the model without interaction terms produces biased and inconsistent estimators due to the misspecification of model. Particularly, in all the specifications without interaction terms, the coefficient on religion is significantly biased downwards and the effect of religion on life satisfaction and perceptions of the economic and political situation is negative. As shown in Tables 5 to 7, while controlling for endogeneity of religion and interaction terms, religion affects happiness in transition countries positively in all three specifications: life satisfaction, and perceptions of the economic and political situation. As described above, a positive effect of religion on life satisfaction has been found in previous literature already, 
but without controlling for endogeneity (see Ellison, 1991; Clark and Lelkes, 2006 and 2009; Lelkes, 2006, among others). Higher religiousness increases the predicted probabilities of being satisfied and strongly satisfied (see Tables A3 to A5 in the Appendix). As such, a hypothetical move from 0 to 100 percent religious increases the probability of being satisfied and strongly satisfied, on average, by 3 and 2 percentage points, respectively. This result is even stronger for perceptions of the political situation: higher religiousness implies about a 6 percent increase in satisfaction with the political situation. The increase in religiousness by 1 standard deviation increases the probability of being strongly satisfied with life by $8.9 \%$ and satisfied with life by $25.1 \%$. The marginal effects of religion in other specifications are less than in the case of life satisfaction, but still sound: $7.7 \%$ and $21.8 \%$ for perceptions of the economic situation and $5.3 \%$ and $14.6 \%$ for perceptions of the political situation (see Tables A6b to A8b in the Appendix).

Previous literature suggests negative effects of some macroeconomic variables (e.g., unemployment, income inequality or inflation) on happiness (see Clark and Oswald, 1994; Di Tella et al., 2001, among others). The effects of economic reforms on happiness have not been yet investigated in previous studies. Since transition period reforms affected various dimensions of economic, political and social life in transition countries and happiness is affected by macroeconomic instabilities, I expect that reforms in transition countries are likely to affect happiness too. Such expectation is also in line with the data and arguments of previous research (for instance, Sanfey and Teksoz, 2005; Lelkes, 2006, Easterlin, 2009) that in the transition period individual happiness decreases. I study how progress in major reforms, namely large and small scale privatization, enterprise restructuring, price liberalization, trade and foreign exchange system, competition policy, banking reform and interest rate liberalization, securities markets and non-bank financial institutions, and overall infrastructure reform, affect individual happiness in transition countries.

As the results of this study indicate, while happiness, perceptions of the eco- 
nomic and political situation, are negatively affected by large scale privatization and positively by price liberalization (not significant in the case of life satisfaction), the effects of other reforms differ for happiness and perceptions of the economic and political situation. Life satisfaction is negatively affected by competition policy and infrastructure reform and positively by small scale privatization, governance reform and enterprise restructuring. Perceptions of the economic situation are negatively affected by small scale privatization and positively by trade and foreign exchange system reform, competition policy and infrastructure reform. Perceptions of the political situation are negatively affected by trade and foreign exchange system reform and the results are not significant for the remaining reforms.

Consistently with most findings in happiness literature, I find that life satisfaction is U-shaped in age; women are happier than men (though the result is not significant); happiness increases with the degree of education; household size positively affects happiness; divorce lowers life satisfaction and marriage increases it (the result is not significant for perceptions of the economic and political situation); the unemployed are less happy than the employed.

\subsection{Religion, Reforms and Life Satisfaction: Interaction Ef- fects}

As we underlined above, some reforms may have negative effects on life satisfaction and perceptions of the economic and political situation and some may have positive effects. As expected, interaction effects in most of the cases are found to be positive if the direct effect of reform is negative, and negative if the direct effect of reform is positive. As the paper finds, religion can insure life satisfaction against negative effects of large scale privatization, competition policy and overall infrastructure reforms. Perceptions of the economic and political situation can be insured against the negative effect of small scale privatization. In the case of life satisfaction, the 
interaction effects of small scale privatization, governance reform and enterprise restructuring are found to be negative while direct effects of these reforms are positive. In the case of perceptions of the economic situation, significant negative interaction effects are found for trade and foreign exchange system reform, competition and overall infrastructure reforms. In the case of perceptions of the political situation, significant negative interaction effects are found for price liberalization and competition policy reform. For the rest of reforms the sign of the interaction term is typically opposite the sign of the direct effect but not significant.

Thus, the main finding of this paper is that religion indeed insures against some aggregate shocks: religious people have lower decreases in happiness than nonreligious people. The effect holds in the opposite direction too: if the main effect from reform is positive, religious people tend to benefit in happiness less than nonreligious. Therefore, religion in general tends to reduce the happiness vulnerability due to aggregate shocks.

\subsection{Robustness Check}

To show that the results are not driven by the choice of estimation method, I also present the results obtained by using the linear probability model. Redefining the dependent variables into a zero/one scale (all dissatisfied/all satisfied) reduces the variation in happiness and perceptions of the economic and political situation, but allows the robustness of results obtained by using ordered logit to be checked. The coefficients of the linear probability model are comparable with the joint marginal effects obtained by using ordered logit for the categories. However, given the aggregation of the dependent variable, one would expect noisier and lower coefficient estimates obtained by using the linear probability model in comparison to ordered logit.

As shown in Tables 8 to 10, the results obtained by using the linear probability model are in fact less significant than in the case of ordered logit, especially in the 
specifications for perceptions of the economic and political situation. The magnitude of coefficient estimates from the LPM for most variables is lower than the marginal effects of explanatory variables on the probabilities of being satisfied and strongly satisfied when summed up. In the case when instrumental variables are used, the size of this difference between LPM and ordered logit is typically comparable with the marginal effect on the middle category "neither disagree, nor agree", observations on which are excluded when a dependent variable for LPM is constructed (see Tables A6b to A8b in the Appendix). Thus, the magnitudes of the effects of explanatory variables on dependent variables are robust to the estimation method used.

As the results indicate, in all three specifications the signs of estimated coefficients obtained by using the linear probability model are the same as the signs of marginal effects obtained by using ordered logit for the categories "agree" and "strongly agree" with a few exceptions, where, nonetheless, the coefficients are not significant in both methods. Thus, the insurance effect of religion against aggregate shocks to happiness and perceptions of economic and political situation is found also using the linear probability model.

\subsection{The Effects of Controlling for Endogeneity}

The estimation of the model without controlling for endogeneity of religion and interaction terms produces biased and inconsistent estimators. As shown in Tables 5 and 8, the estimation of ordered logit and LPM without controlling for endogeneity produces the estimate of the coefficient on religion which is, as expected, biased downwards in the specification for life satisfaction. Also, in the specifications for perceptions of the economic and political situation, marginal effects of religion become larger after controlling for endogeneity. Given the downward bias in the estimate of the coefficient for religion when we do not control for endogeneity, we may expect that the source of endogeneity is not solely in the time constant unobservables that are likely to affect both happiness and religiousness, as described above, but also 
in simultaneity between happiness and religion. Since instability during transition period is stressful for people and makes them unhappy, there may be a temporal reaction: unhappy people are likely to become religious during stressful life events. Thus, when we do not control for endogeneity (in both ordered logit and LPM), this negative reverse causality between happiness and religiousness biases the coefficients downwards.

The interaction coefficients are also changing in all specifications after controlling for endogeneity. For most interaction terms, the absolute value of coefficients gets larger in all specifications in both ordered logit and LPM. Thus, controlling for endogeneity makes the insurance effects stronger. This is an expected change since direct effects of religion also become larger.

Controlling for endogeneity of religion and interaction terms changes the estimated coefficients in LPM and marginal effects in ordered logit in the same direction, though the size of the change for some variables is less when LPM is used. This difference may again be because of the aggregation of the dependent variable.

\section{Conclusion}

Religiousness insures happiness against individual stressful life events and, therefore, religious people are more likely to adapt easier to idiosyncratic shocks and feel happier during various changes (Clark and Lelkes, 2006; Lelkes, 2006; Dehejia et al., 2007). This paper accounts for the endogeneity of religion in the happiness equation and consider major economic reforms in transition countries as aggregate shocks to happiness. As underlined in the paper, the insurance effect of religion found in previous literature for idiosyncratic shocks is also applicable for overcoming the effects of aggregate shocks. I argue that religion may also insure against negative aggregate shocks to happiness and reduce the happiness vulnerability in the case of positive shocks. This result is robust to the choice of estimation method and holds 
for all three specifications in the paper, namely life satisfaction, and perception of the current economic and political situation. In line with previous research the paper also finds that happiness is U-shaped in age, more educated people are happier, the employed are happier than the unemployed, and happiness increases with household size and marriage and decreases with divorce.

As this paper argues, people in more religious countries are likely to be more satisfied with life, and the economic and political situation. Higher religiousness is associated with a strong increase in the probabilities of being satisfied and strongly satisfied: an increase in religiousness by 1 standard deviation increases the probability of being strongly satisfied with life by $8.9 \%$ and satisfied with life by $25.1 \%$. In a hypothetical case when a country moves from 0 to 100 percent religious, the share of satisfied and strongly satisfied people increases, on average, by 3 and 2 percentage points, respectively. Thus, the happiness ranking of religious countries is likely to be higher.

A decrease in happiness observed in transition countries during the transition period may be due to the negative effects of reforms, e.g., large scale privatization and overall infrastructure reform. Because of the insurance effect of religion found in this paper, transition countries with higher shares of religious people are likely to experience reforms with less vulnerability in happiness. This may also imply that reforms in more religious countries are likely to gain support and be implemented faster than in less religious countries. 


\section{References}

[1] Alesina, A., Di Tella, R., MacCulloch, R. (2004). Inequality and Happiness: Are Europeans and Americans Different? The Journal of Public Economics, 88, 2009-2042.

[2] Azzi, C., Ehrenberg, R. (1975). Household Allocation of Time and Church Attendance, The Journal of Political Economy, 83(1), 27-56.

[3] Bettendorf, L., Dijkgraaf, E. (2010). Religion and Income: Heteregeneity between Countries. The Journal of Economic Behavior and Organization, 74, $12-29$.

[4] Blanchflower, D., Oswald, A. (2004). Well-being over Time in Britain and the USA. The Journal of Public Economics, 88, 1359-1386.

[5] Blundell, R., Smith, R. (1994). Coherency and Estimation in Simultaneous Models with Censored or Qualitative Dependent Variables. The Journal of Econometrics, 64, 355-373.

[6] Cameron, A., Trivedi, P. (2005). Microeconometrics: Methods and Applications. Cambridge: Cambridge University Press.

[7] Clark, A., Lelkes, O. (2009). Let Us Pray: Religious Interactions in Life Satisfaction. Paris School of Economics Working Paper \# 2009-01.

[8] Clark, A., Lelkes, O. (2006). Deliver Us from Evil: Religion as Insurance, Papers on Economics of Religion 06/03, Department of Economic Theory and Economic History of the University of Granada.

[9] Clark, A., Oswald, A. (1994). Unhappiness and Unemployment. The Economic Journal, 104, 648-659.

[10] Dehejia, R., DeLeire, T., Luttmer, E. (2007). Insuring Consumption and Happiness through Religious Organizations. The Journal of Public Economics, 91, 259-279.

[11] Di Tella, R., MacCulloch, R. (2006). Some Uses of Happiness Data in Economics. The Journal of Economic Perspectives, 20(1), 25-46.

[12] Di Tella, R., MacCulloch, R., Oswald, A. (2001). Preferences over Inflation and Unemployment: Evidence from Surveys of Happiness. The American Economic Review, 91, 335-341.

[13] Di Tella, R., MacCulloch, R., Oswald, A. (2003). The Macroeconomics of Happiness. The Review of Economics and Statistics, 85, 809-827.

[14] Donald, S., Lang, K.(2007) Inference with Difference in Differences and Other Panel Data.The Review of Economics and Statistics, 89(2): 221-233.

[15] Dynan, K., Ravina, E. (2007). Increasing Income Inequality, External Habits, and Self-Reported Happiness. The American Economic Review, 97(2), 226231 .

[16] Easterlin, R. (1974). Does Economic Growth Improve the Human Lot? Some Empirical Evidence. In Nations and Households in Economic Growth: Es- 
says in Honor of Moses Abramovitz. P. David and M. Reder, eds. New York and London: Academic Press, 98-125.

[17] Easterlin, R. (1995). Will Raising the Incomes of All Increase the Happiness of All? The Journal of Economic Behavior and Organization, 27, 35-47.

[18] Easterlin, R. (2001). Income and Happiness: Towards a Unified Theory. The Economic Journal, 111, 465-484.

[19] Easterlin, R. (2009). Lost in Transition: Life Satisfaction on the Road to Capitalism. The Journal of Economic Behavior and Organization, 71, 130-145.

[20] EBRD (2006). Transition Report 2006: Finance in Transition, London, EBRD.

[21] Ellison, C. (1991). Religious Involvement and Subjective Well-Being. The Journal of Health and Social Behavior, 32(1), 80-99.

[22] Ferrer-i-Carbonell, A. (2005). Income and Well-being: an Empirical Analysis of the Comparison Income Effect. The Journal of Public Economics, 89, 997-1019.

[23] Frey, B., Stutzer, A. (2000). Happiness, Economy and Institutions. The Economic Journal, 110(466), 918-938.

[24] Frey, B., Stutzer, A. (2002a). Happiness and Economics: How the Economy and Institutions Affect Human Well-Being. Princeton and Oxford: Princeton University Press.

[25] Frey, B., Stutzer, A. (2002b). What Can Economists Learn from Happiness Research? The Journal of Economic Literature, XL(2), 402-435.

[26] Gerdtham, U., Johannesson, M. (2001). The Relationship between Happiness, Health, and Socio-Economic Factors: Results Based on Swedish Microdata. The Journal of Socio-Economics, 30, 553-557.

[27] Graham, C., Eggers, A., Sukhtankar, S. (2004). Does Happiness Pay? An Exploration Based on Panel Data from Russia. The Journal of Economic Behavior and Organization, 55, 319-342.

[28] Greene, W. (2003). Econometric Analysis, 5th ed., Prentice Hall.

[29] Gruber, J. (2005). Religious Market Structure, Religious Participation, and Outcomes: Is Religion Good for You? Advances in Economic Analysis and Policy, 5(1), 1454-1454.

[30] Guiso, L., Sapienza, P., Zingales, L., (2003). People's Opium? Religion and Economic Attitudes. The Journal of Monetary Economics, 50, 225-282.

[31] Guriev, S., Zhuravskaya, E. (2009). (Un)Happiness in Transition. The Journal of Economic Perspectives, 23(2), 143-168.

[32] Hadaway, C. (1978). Life Satisfaction and Religion: A Re-analysis. Social Forces, 57(2), 636-643.

[33] Hayo, B. (2007). Happiness in Transition: An Empirical Study on Eastern Europe. Economic Systems, 31(2), 204-221.

[34] Hayo, B., Seifert, W. (2003). Subjective Economic Well-being in Eastern Europe. The Journal of Economic Psychology, 24(3), 329-348. 
[35] Hausman, J. (1978). Specification Tests in Econometrics. Econometrica, 46(6), 1251-1271.

[36] Kahnemann, D., Wakker, P., Sarin, R. (1997). Back to Bentham? Explorations of Experienced Utility. The Quarterly Journal of Economics, 112(2), 375405.

[37] Kalyuzhnova, Y., Kambhampati, U. (2008). The Determinants of Individual Happiness in Kazakhstan. Economic Systems, 32(3), 285-299.

[38] Kmenta, J. (1997). Elements of Econometrics, 2nd ed., University of Michigan Press.

[39] Konow, J., Earley, J. (2008). The Hedonistic Paradox: Is Homo Economicus Happier? The Journal of Public Economics, 92(1-2), 1-33.

[40] Lelkes, O. (2006). Tasting Freedom: Happiness, Religion and Economic Transition. The Journal of Economic Behavior and Organization, 59, 173-194.

[41] Luttmer, E. (2005). Neighbors as Negatives: Relative Earnings and Well-being. The Quarterly Journal of Economics, 120(3), 963-1002.

[42] Lyubomirsky, S., Sheldon, K., Schkade, D. (2005). Pursuing Happiness: The Architecture of Sustainable Change. The Review of General Psychology, $9(2), 111-131$.

[43] Maddala, G. (1983). Limited Dependent and Qualitative Variables in Econometrics. Cambridge: Cambridge University Press.

[44] Michalos, A., Zumbo, B. (2000). Criminal Victimization and the Quality of Life. Social Indicators Research, 50(3), 245-295.

[45] Mookerjee, R., Beron, K. (2005). Gender, Religion and Happiness. The Journal of Socio-Economics, 34, 674-685.

[46] Morawetz, D., Atia, E., Bin-Nun, G., Felous, L., Gariplerden, Y., Harris, E., Soustiel, S., Tombros, G., Zarfaty, Y. (1977). Income Distribution and Self-Rated Happiness: Some Empirical Evidence. The Economic Journal, 87(347), 511-522.

[47] Namazie, C., Sanfey, P. (2001). Happiness and Transition: the Case of Kyrgyzstan. The Review of Development Economics, 5(3), 392-405.

[48] Need, A., Evans, G. (2001). Analyzing Patterns of Religious Participation in Post-Communist Eastern Europe. The British Journal of Sociology, 52(2), 229-248.

[49] Ozer-Balli, H., Sorensen, B. (2010). Interaction Effects in Econometrics. CEPR Discussion Paper \#7929.

[50] Powdthavee, N. (2005). Unhappiness and Crime: Evidence from South Africa. Economica, 72, 531-547.

[51] Putnam, R. (1993). What Makes Democracy Work? National Civic Review, 82(2), 101-107.

[52] Rehdanz, K., Maddison, D. (2005). Climate and Happiness. Ecological Economics, 52, 111-125. 
[53] Sanfey, P., Teksoz, U. (2007). Does Transition Make You Happy? The Economics of Transition, 15(4), 707-731.

[54] Stock, J., Yogo, M. (2005). Testing for Weak Instruments in Linear IV Regression. In Identification and Inference for Econometric Models: Essays in Honor of Thomas Rothenberg, ed. D. Andrews and J. Stock, 80-108. Cambridge: Cambridge University Press.

[55] Tomka, M. (1994). The Sociology of Religion in Eastern and Central Europe: Problems of Teaching and Research after the Breakdown of Communism, Social Compass, 41(3), 379-392.

[56] Veenhoven, R. (2001). Are the Russians as Unhappy as They Say They Are? The Journal of Happiness Studies, 2, 111-136.

[57] Welsch, H. (2007). Environmental Welfare Analysis: A Life Satisfaction Approach. Ecological Economics, 62, 544-551.

[58] Winkelmann, L., Winkelmann, R. (1998). Why are the Unemployed So Unhappy? Evidence from Panel Data. Economica, 65(257), 1-15.

[59] Wooldridge, J. (2002). Introductory Econometrics: A Modern Approach, 2d edition, MIT press. 


\section{Appendix}

\section{A1. Model Details}

The system of structural equations is

$$
\begin{aligned}
& \mathbf{B y}_{i t c}+\boldsymbol{\Gamma} \mathbf{x}_{i t c}=\mathbf{u}_{i t c} \text {, where }
\end{aligned}
$$

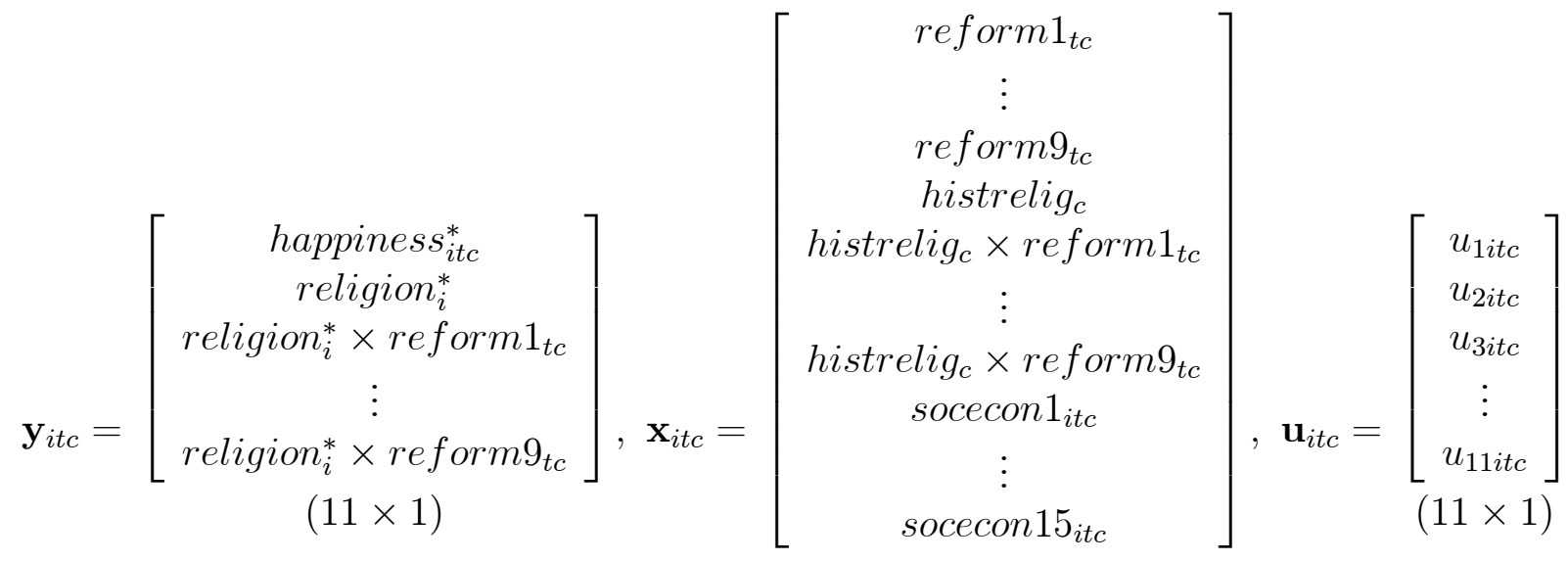

$$
\begin{aligned}
& (34 \times 1) \\
& \mathbf{B}=\left[\begin{array}{ccccc}
1 & -\beta_{12} & -\beta_{13} & \cdots & -\beta_{111} \\
-\beta_{21} & 1 & 0 & \cdots & 0 \\
-\beta_{31} & 0 & 1 & & \vdots \\
\vdots & \vdots & & \ddots & 0 \\
-\beta_{11} & 0 & \cdots & 0 & 1
\end{array}\right] \\
& (11 \times 11) \\
& \boldsymbol{\Gamma}=\left[\begin{array}{ccccccccc}
-\gamma_{11} & \cdots & -\gamma_{19} & 0 & \cdots & 0 & -\gamma_{120} & \cdots & -\gamma_{134} \\
0 & \cdots & 0 & -\gamma_{210} & \cdots & -\gamma_{219} & -\gamma_{220} & \cdots & -\gamma_{234} \\
0 & \cdots & 0 & -\gamma_{310} & \cdots & -\gamma_{319} & -\gamma_{320} & \cdots & -\gamma_{33} \\
\vdots & & \vdots & \vdots & & \vdots & \vdots & & \vdots \\
0 & \cdots & 0 & -\gamma_{1110} & \cdots & -\gamma_{1119} & -\gamma_{1120} & \cdots & -\gamma_{1134}
\end{array}\right] \\
& (11 \times 34)
\end{aligned}
$$

The system of reduced form equations is

$$
\begin{gathered}
\mathbf{y}_{i t c}=\boldsymbol{\Pi} \mathbf{x}_{i t c}+\boldsymbol{\nu}_{i t c}, \text { where } \\
\boldsymbol{\Pi}=\left[\begin{array}{cccc}
\pi_{11} & \pi_{12} & \cdots & \pi_{134} \\
\pi_{21} & \pi_{22} & \cdots & \pi_{234} \\
\vdots & \vdots & & \vdots \\
\pi_{11} & \pi_{112} & \cdots & \pi_{1134}
\end{array}\right], \boldsymbol{\nu}_{i t c}=\underset{(11 \times 1)}{(11 \times 34)}
\end{gathered}
$$


A2. Main Tables

Table 1. World Happiness.

\begin{tabular}{l|c|c}
\hline \multicolumn{1}{c|}{ Country } & Very Happy (\%) & Satisfied (\%) \\
\hline Denmark & 44.9 & 90.8 \\
Finland & 24.1 & 88.3 \\
Colombia & 47.1 & 88.1 \\
Iceland & 46.6 & 86.7 \\
Puerto Rico & 53.3 & 85.2 \\
Switzerland & 39.9 & 84.8 \\
Netherlands & 45.9 & 84.2 \\
Northern Ireland & 46.1 & 84.0 \\
Sweden & 36.6 & 82.1 \\
Austria & 35.4 & 81.7 \\
Canada & 44.0 & 80.7 \\
Belgium & 42.4 & 80.4 \\
Germany West & 18.9 & 79.6 \\
Ireland & 42.0 & 79.0 \\
Luxembourg & 35.4 & 78.9 \\
United States & 39.0 & 78.7 \\
Norway & 30.0 & 78.4 \\
Germany East & 20.3 & 78.0 \\
Mexico & 56.5 & 77.7 \\
Australia & 42.9 & 76.9 \\
New Zealand & 33.3 & 75.9 \\
Great Britain & 32.5 & 75.7 \\
Spain & 20.1 & 74.7 \\
Italy & 18.2 & 74.6 \\
Malta & 31.1 & 72.5 \\
Singapore & 28.7 & 70.6 \\
Venezuela & 56.8 & 69.9 \\
Slovenia & 15.2 & 68.7 \\
Argentina & 33.0 & 68.4 \\
France & 31.3 & 65.1 \\
Israel & 27.2 & 65.0 \\
Saudi Arabia & 44.3 & 64.5 \\
Nigeria & 66.8 & 63.7 \\
Chile & 36.0 & 62.6 \\
Brazil & 22.0 & 62.5 \\
Greece & 18.2 & 62.3 \\
Indonesia & 60.4 & 60.9 \\
Czech Republic & 53.7 \\
Philippines & Croatia & 53.5 \\
China & India & 53.5 \\
Kyrgyzstan & Iran & \\
& 12.5 \\
\hline
\end{tabular}

\begin{tabular}{l|c|c}
\hline \multicolumn{1}{c|}{ Country } & Very Happy (\%) & Satisfied (\%) \\
\hline Japan & 27.8 & 51.4 \\
Peru & 30.8 & 49.8 \\
Republic of Korea & 9.6 & 46.3 \\
Poland & 17.4 & 45.6 \\
Viet Nam & 48.6 & 44.1 \\
Egypt & 18.1 & 43.4 \\
Portugal & 18.0 & 43.4 \\
Algeria & 16.1 & 43.3 \\
South Africa & 38.5 & 42.0 \\
Hungary & 16.7 & 41.8 \\
Slovakia & 8.0 & 41.7 \\
Estonia & 6.5 & 41.6 \\
Turkey & 34.5 & 40.6 \\
Romania & 3.6 & 40.2 \\
Montenegro & 8.1 & 39.7 \\
Serbia & 12.0 & 39.4 \\
Morocco & 30.8 & 38.4 \\
Bosnia and Herzegovina & 21.7 & 37.9 \\
Jordan & 12.8 & 37.0 \\
Uganda & 26.2 & 35.9 \\
Latvia & 6.6 & 34.8 \\
Bangladesh & 14.8 & 31.9 \\
Azerbaijzan & 11.3 & 31.2 \\
Iraq & 13.2 & 30.9 \\
Lithuania & 3.8 & 30.9 \\
Macedonia & 19.1 & 30.7 \\
Armenia & 6.3 & 28.5 \\
Russian Federation & 6.0 & 28.0 \\
Georgia & 11.7 & 24.6 \\
Ukraine & 5.8 & 23.7 \\
Belarus & 4.9 & 23.4 \\
Tanzania & 56.2 & 20.6 \\
Moldova & 6.0 & 18.5 \\
Zimbabwe & 19.9 & 18.0 \\
Bulgaria & 7.8 & 16.8 \\
Pakistan & 19.6 & 8.3 \\
Albania & $2005)$ \\
\hline \hline Sourcs: Wor & . & \\
\hline
\end{tabular}

Sources: World Values Survey (2005), World Database of Happiness (2005). Notes: Countries are ranked according to the percentage of those satisfied with life. Transition countries are shaded. Happiness measure: 'Taking all things together, would you say you are very happy, quite happy, not very happy, or not at all happy?' Life satisfaction measure: 'All things considered, how satisfied are you with your life as a whole these days?' Ten-point scale: $1=$ dissatisfied, and $10=$ satisfied; percent 'satisfied'-scores 7-10. 
Table 2. Variables Description.

\begin{tabular}{|c|c|}
\hline Variable & Detailed Description \\
\hline Life Satisfaction & $\begin{array}{l}\text { To what extent do you agree with the following statement: All things considered, I am } \\
\text { satisfied with my life now, Strongly disagree }=1 \text {, Disagree }=2 \text {, Neither disagree nor agree } \\
=3 \text {, Agree }=4 \text {, Strongly agree }=5 \text {. Source: LiTS }\end{array}$ \\
\hline Perception of Current Economic Situation & $\begin{array}{l}\text { To what extent do you agree with the following statement: The economic situation in this } \\
\text { country is better today than around } 1989 \text {, Strongly disagree }=1 \text {, Disagree }=2 \text {, Neither } \\
\text { disagree nor agree }=3 \text {, Agree }=4 \text {, Strongly agree }=5 \text {. Source: } \operatorname{LiTS}\end{array}$ \\
\hline Perception of Current Political Situation & $\begin{array}{l}\text { To what extent do you agree with the following statement: The political situation in this } \\
\text { country is better today than around } 1989 \text {, Strongly disagree }=1 \text {, Disagree }=2 \text {, Neither } \\
\text { disagree nor agree }=3 \text {, Agree }=4 \text {, Strongly agree }=5 \text {. Sourse: LiTS }\end{array}$ \\
\hline Life Satisfaction, redefined into $0 / 1$ & $\begin{array}{l}\text { Dummy variable }=1 \text { if the respondent answered Agree }=4 \text {, Strongly agree }=5 \text { on the } \\
\text { question about life satisfaction, and } 0 \text { if the answer was Strongly disagree }=1 \text {, } \\
\text { Disagree }=2 \text {. Observations with the answer Neither disagree nor agree }=3 \text { are dropped. } \\
\text { Source: author's calculations }\end{array}$ \\
\hline $\begin{array}{l}\text { Perception of Current Economic Situation, } \\
\text { redefined into } 0 / 1\end{array}$ & $\begin{array}{l}\text { Dummy variable }=1 \text { if the respondent answered Agree }=4 \text {, Strongly agree }=5 \text { on the } \\
\text { question about the perception of current economic situation, and } 0 \text { if the answer was } \\
\text { Strongly disagree }=1 \text {, Disagree }=2 \text {. Observations with the answer Neither disagree nor } \\
\text { agree }=3 \text { are dropped. Source: author's calculations }\end{array}$ \\
\hline $\begin{array}{l}\text { Perception of Current Political Situation, } \\
\text { redefined into } 0 / 1\end{array}$ & $\begin{array}{l}\text { Dummy variable }=1 \text { if the respondent answered Agree }=4 \text {, Strongly agree }=5 \text { on the } \\
\text { question about the perception of current political situation, and } 0 \text { if the answer was } \\
\text { Strongly disagree }=1 \text {, Disagree }=2 \text {. Observations with the answer Neither disagree nor } \\
\text { agree }=3 \text { are dropped. Source: author's calculations }\end{array}$ \\
\hline $\begin{array}{l}\text { Ln (Number of people of given religion in } \\
\text { a given country in 1900) }\end{array}$ & $\begin{array}{l}\text { Data based on church statistics, government censuses, United Nations statistics, and } \\
\text { estimates of informed experts. Source: WCD, author's calculations. }\end{array}$ \\
\hline Religion & $\begin{array}{l}\text { Dummy variable }=1 \text { if the respondent answered Buddhist, Jewish, Christian, Muslim, } \\
\text { Other to the question "What is your religion?", and } 0 \text { if the answer was } \\
\text { Atheistic/Agnostic/None. Source: LiTS, author's calculations }\end{array}$ \\
\hline $\begin{array}{l}\text { Large, Small Scale Privatization, } \\
\text { Enterprise Restructuring, } r \text { Price } \\
\text { Liberalization, Trade and Foreign } \\
\text { Exchange System, Competition Policy, } \\
\text { Banking Reform and Interest Rate } \\
\text { Liberalization, Securities Market and Non- } \\
\text { Bank Financial Institutions, Overall } \\
\text { Infrastructure Reform }\end{array}$ & $\begin{array}{l}\text { Change in corresponding EBRD transition index calculated as a difference between index } \\
\text { score in } 2006 \text { and index score in } 1989 \text { for each transition country. EBRD transition indices } \\
\text { have the range from } 1 \text { to } 4.3(4+) \text { where the higher the index reflects higher progress in } \\
\text { corresponding area of reforms (large scale privatization, small scale privatization, } \\
\text { enterprise restructuring, price liberalization, trade and foreign exchange system, } \\
\text { competition policy, banking reform and interest rate liberalization, securities markets and } \\
\text { non-bank financial institutions, overall infrastructure reform). Source: EBRD transition } \\
\text { indicators, author's calculations }\end{array}$ \\
\hline Age & Age of respondent. Source: LiTS \\
\hline Age Squared/100 & Source: LiTS, author's calculations \\
\hline Male & Dummy for the gender of respondent: Male 1 , Female 0 . Source: LiTS \\
\hline Basic School & $\begin{array}{l}\text { Dummy variable }=1 \text { if the highest degree that respondent obtained is basic education, } \\
\text { and } 0 \text {, otherwise. Source: LiTS }\end{array}$ \\
\hline Secondary School & $\begin{array}{l}\text { Dummy variable }=1 \text { if the highest degree that respondent obtained is secondary } \\
\text { education, and } 0 \text {, otherwise. Source: LiTS }\end{array}$ \\
\hline Vocational/Professional School & $\begin{array}{l}\text { Dummy variable }=1 \text { if the highest degree that respondent obtained is professional, } \\
\text { vocational school/training, and } 0 \text {, otherwise. Source: LiTS }\end{array}$ \\
\hline Higher Degree (University, College) & $\begin{array}{l}\text { Dummy variable }=1 \text { if the highest degree that respondent obtained is higher professional } \\
\text { degree (university, college), and } 0 \text {, otherwise. Source: LiTS }\end{array}$ \\
\hline Postgraduate Degree & $\begin{array}{l}\text { Dummy variable }=1 \text { if the highest degree that respondent obtained is postgraduate } \\
\text { degree, and } 0 \text {, otherwise. Source: LiTS }\end{array}$ \\
\hline Children & Number of children less than 14 years old. Source: LiTS \\
\hline Children Born/Adopted 1990-2006 & $\begin{array}{l}\text { Dummy variable }=1 \text { if respondent had a child (birth or adoption) during 1990-2006, and } \\
\text { 0, otherwise. Source: LiTS, author's calculations }\end{array}$ \\
\hline Married 1990-2006 & $\begin{array}{l}\text { Dummy variable }=1 \text { if respondent got married (lived in a couple) during 1990-2006, and 0, } \\
\text { otherwise. Source: LiTS, author's calculations }\end{array}$ \\
\hline Divorced 1990-2006 & $\begin{array}{l}\text { Dummy variable }=1 \text { if respondent divorced during 1990-2006, and 0, otherwise. Source: } \\
\text { LiTS, author's calculations }\end{array}$ \\
\hline Household Size & Source: LiTS \\
\hline $\begin{array}{l}\text { Household } \text { Consumption Expenditures } \\
\text { Equalized Using the Modified OECD } \\
\text { Scales }\end{array}$ & $\begin{array}{l}\text { Household consumption per month in USD. OECD-modified scales assign to each } \\
\text { household a value in proportion to needs of every member: a value of } 1 \text { to the household } \\
\text { head, of } 0.5 \text { to each additional adult member and of } 0.3 \text { to each child. Source: LiTS }\end{array}$ \\
\hline Employment & $\begin{array}{l}\text { Dummy variable }=1 \text { if respondent worked at least one hour during last } 7 \text { days, and } 0 \text {, } \\
\text { otherwise. Source: LiTS }\end{array}$ \\
\hline
\end{tabular}


Table 3. Descriptive Statistics.

\begin{tabular}{|c|c|c|c|c|c|}
\hline Variable & Obs & Mean & Std. Dev. & Min & $\operatorname{Max}$ \\
\hline Life Satisfaction & 27381 & 3.101 & 1.148 & 1 & 5 \\
\hline Perception of Current Economic Situation & 25136 & 2.737 & 1.268 & 1 & 5 \\
\hline Perception of Current Political Situation & 24312 & 2.811 & 1.227 & 1 & 5 \\
\hline Life Satisfaction, redefined into 0/1 & 20995 & 0.579 & 0.494 & 0 & 1 \\
\hline Perception of Current Economic Situation, redefined into 0/1 & 21187 & 0.416 & 0.493 & 0 & 1 \\
\hline Perception of Current Political Situation, redefined into 0/1 & 19157 & 0.445 & 0.497 & 0 & 1 \\
\hline Religion & 27392 & 0.898 & 0.302 & 0 & 1 \\
\hline Ln (Number of people of given religion in a given country in 1900) & 26403 & 14.018 & 2.209 & 3.912 & 17.935 \\
\hline Large Scale Privatization & 27392 & 2.179 & 0.786 & 0 & 3 \\
\hline Small Scale Privatization & 27392 & 2.406 & 1.026 & 0 & 3.330 \\
\hline Governance and Enterprise Restructuring & 27392 & 1.469 & 0.723 & 0 & 2.670 \\
\hline Price Liberalization & 27392 & 2.510 & 0.957 & 0 & 3.330 \\
\hline Trade and Foreign Exchange System & 27392 & 2.629 & 0.892 & 0 & 3.330 \\
\hline Competition Policy & 27392 & 1.349 & 0.676 & 0 & 2.670 \\
\hline Banking Reform and Interest Rate Liberalization & 27392 & 1.994 & 0.734 & 0 & 3.000 \\
\hline Securities Markets and Non-Bank Financial Institutions & 27392 & 1.458 & 0.727 & 0 & 3.000 \\
\hline Overall Infrastructure Reform & 27392 & 1.504 & 0.640 & 0 & 2.340 \\
\hline Age & 27390 & 46.906 & 17.720 & 17 & 97 \\
\hline Age Squared/100 & 27390 & 25.142 & 17.655 & 2.890 & 94.090 \\
\hline Male & 27392 & 0.416 & 0.493 & 0 & 1 \\
\hline Basic School & 27392 & 0.185 & 0.389 & 0 & 1 \\
\hline Secondary School & 27392 & 0.264 & 0.441 & 0 & 1 \\
\hline Voca & 27392 & 0.304 & 0.460 & 0 & 1 \\
\hline Higher Professional Degree (University, College) & 27392 & 0.184 & 0.387 & 0 & 1 \\
\hline Postgraduate Degree & 27392 & 0.009 & 0.092 & 0 & 1 \\
\hline Number of children & 27392 & 0.513 & 0.912 & 0 & 9 \\
\hline Children Born/Adopted between 1990-2006 & 27392 & 0.310 & 0.462 & 0 & 1 \\
\hline Married between 1990-2006 & 27392 & 0.246 & 0.431 & 0 & 1 \\
\hline Divorced between 1990-2006 & 27392 & 0.046 & 0.210 & 0 & 1 \\
\hline Household Size & 27392 & 1.987 & 0.775 & 1 & 6.5 \\
\hline Household Consumption Expenditures Equalized Using the Modified OECD Scales & 27329 & 7.529 & 0.894 & 0.981 & 10.252 \\
\hline Employment & 27392 & 0.484 & 0.500 & 0 & 1 \\
\hline
\end{tabular}

Source: LiTS, EBRD transition indicators, WCD, author's calculations. Notes: LiTS database initially contains 29000 observations from 29 countries. Observations with missing or uncertain answers to the questions about Life Satisfaction, Perception of Current Economic Situation, and Perception of Current Political Situation were removed from the database. Observations for Tajikistan were removed from the database due to inconsistency in religion data with WCD. Observations for Turkey were removed from the database due to absence of EBRD transition indicators. The number of observations slightly differs for different variables due to missing values. 
Table 4. Distribution of answers for dependent variables.

\begin{tabular}{|c|c|c|c|}
\hline Answer & Frequency (obs.) & Percent & Cumulative \\
\hline \multicolumn{4}{|c|}{$\begin{array}{l}\text { To what extent do you agree with the following statement: } \\
\text { All things considered, I am satisfied with my life now }\end{array}$} \\
\hline $\begin{array}{l}\text { (1) Strongly disagree } \\
\text { (2) Disagree } \\
\text { (3) Neither disagree nor agree } \\
\text { (4) Agree } \\
\text { (5) Strongly agree } \\
\quad \text { Total } \\
\end{array}$ & $\begin{array}{c}2836 \\
6003 \\
6386 \\
9876 \\
2280 \\
27381 \\
\end{array}$ & $\begin{array}{c}10.36 \\
21.92 \\
23.32 \\
36.07 \\
8.33 \\
100\end{array}$ & $\begin{array}{c}10.36 \\
32.28 \\
55.60 \\
91.67 \\
100\end{array}$ \\
\hline \multicolumn{4}{|c|}{$\begin{array}{ll}\text { Life Satisfaction, redefined } \\
\end{array}$} \\
\hline $\begin{array}{c}\text { (0) Strongly disagree and Disagree } \\
\text { (1) Agree and Strongly agree } \\
\text { Total }\end{array}$ & $\begin{array}{c}8839 \\
12156 \\
20995\end{array}$ & $\begin{array}{c}42.10 \\
57.90 \\
100\end{array}$ & $\begin{array}{c}42.10 \\
100\end{array}$ \\
\hline
\end{tabular}

\section{Perception of Current Economic Situation}

To what extent do you agree with the following statement:

The economic situation in this country is better today than around 1989

\begin{tabular}{|c|c|c|c|}
\hline $\begin{array}{l}\text { (1) Strongly disagree } \\
\text { (2) Disagree } \\
\text { (3) Neither disagree nor agree } \\
\text { (4) Agree } \\
\text { (5) Strongly agree } \\
\quad \text { Total }\end{array}$ & $\begin{array}{c}5032 \\
7335 \\
3949 \\
6863 \\
1957 \\
25136\end{array}$ & $\begin{array}{c}20.02 \\
29.18 \\
15.71 \\
27.30 \\
7.79 \\
100\end{array}$ & $\begin{array}{c}20.02 \\
49.20 \\
64.91 \\
92.21 \\
100\end{array}$ \\
\hline \multicolumn{4}{|c|}{ Perception of Current Economic Situation, redefined } \\
\hline $\begin{array}{c}\text { (0) Strongly disagree and Disagree } \\
\text { (1) Agree and Strongly agree } \\
\text { Total }\end{array}$ & $\begin{array}{c}12367 \\
8820 \\
21187\end{array}$ & $\begin{array}{c}58.37 \\
41.63 \\
100\end{array}$ & $\begin{array}{c}58.37 \\
100\end{array}$ \\
\hline
\end{tabular}

Perception of Current Political Situation

To what extent do you agree with the following statement:

The political situation in this country is better today than around 1989

\begin{tabular}{l|c|c|c|}
\hline (1) Strongly disagree & 4310 & 17.73 & 17.73
\end{tabular}

(2) Disagree

(3) Neither disagree nor agree

\begin{tabular}{l|l|l}
6314 & 25.97 & 43.70
\end{tabular}

(4) Agree

\begin{tabular}{l|l|l}
5155 & 21.20 & 64.90
\end{tabular}

(5) Strongly agree

\begin{tabular}{l|l|l}
6736 & 27.71 & 92.61
\end{tabular}

\begin{tabular}{l|l|r}
1797 & 7.39 & 100
\end{tabular}

Total \begin{tabular}{l|l}
24312 & 100
\end{tabular}

Perception of Current Political Situation, redefined

\begin{tabular}{c|c|c|c}
\hline (0) Strongly disagree and Disagree & 10624 & 55.46 & 55.46 \\
(1) Agree and Strongly agree & 8533 & 44.54 & 100 \\
Total & 19157 & 100 & \\
\hline \hline
\end{tabular}

Source: LiTS, author's calculations. 


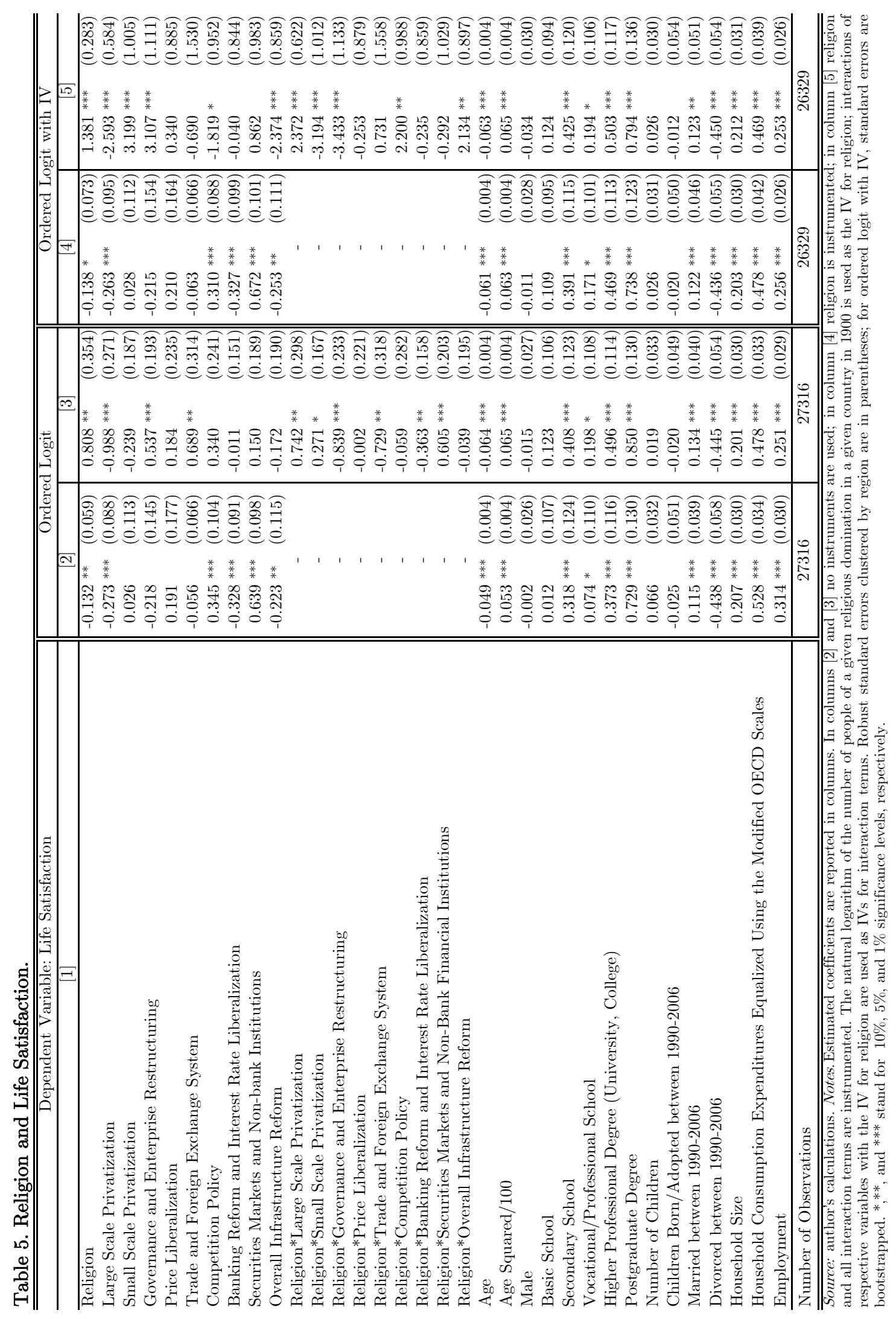




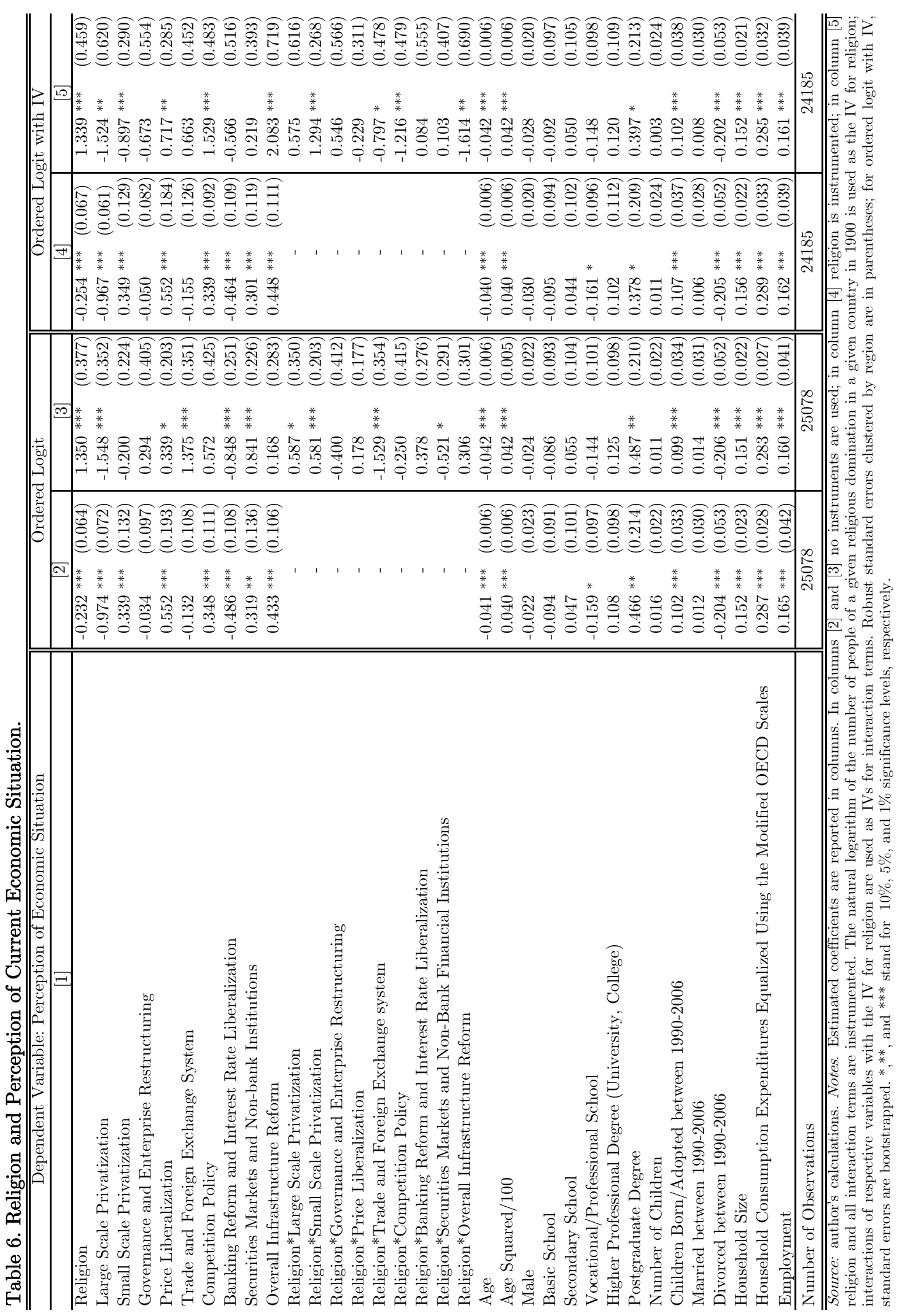




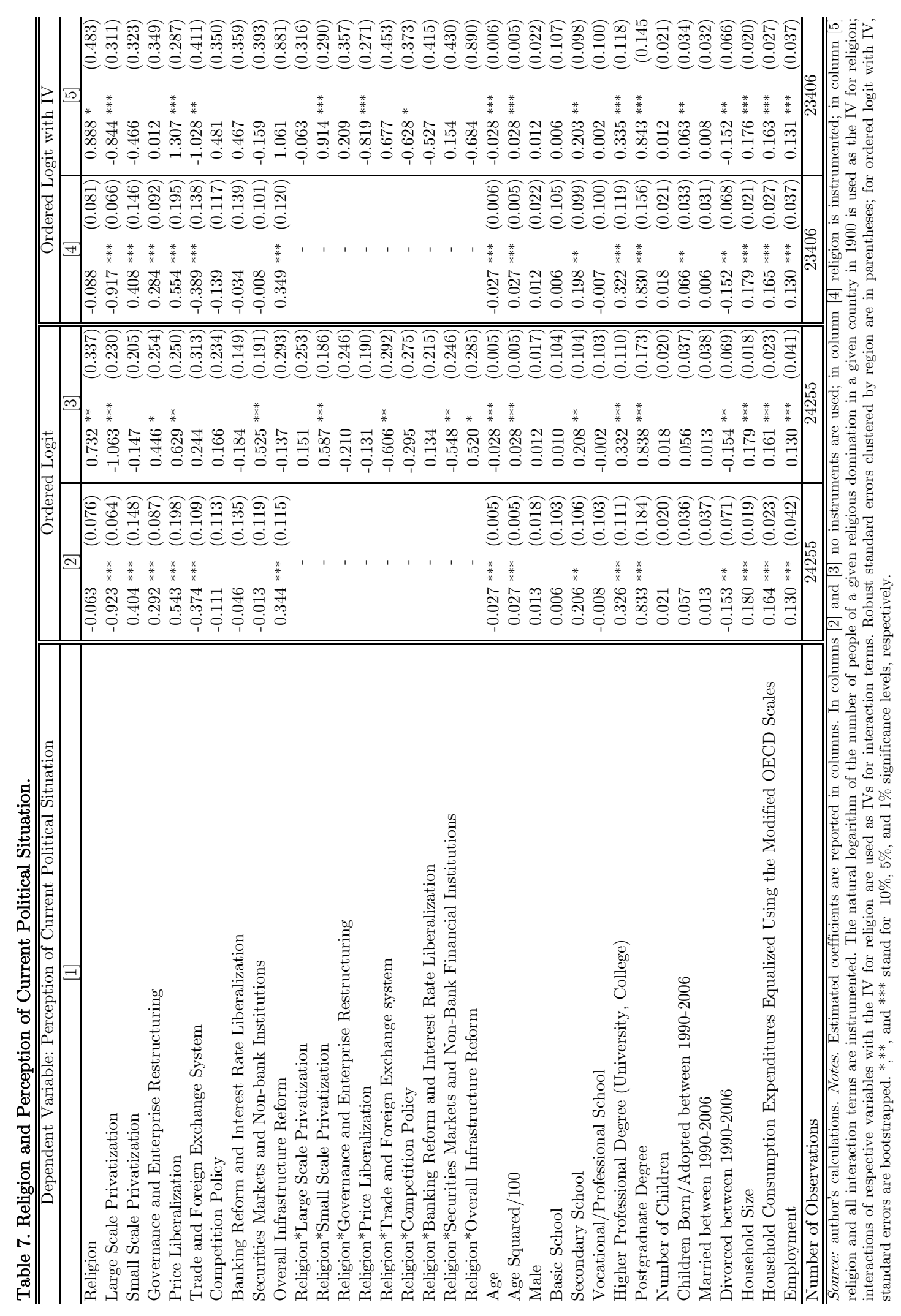




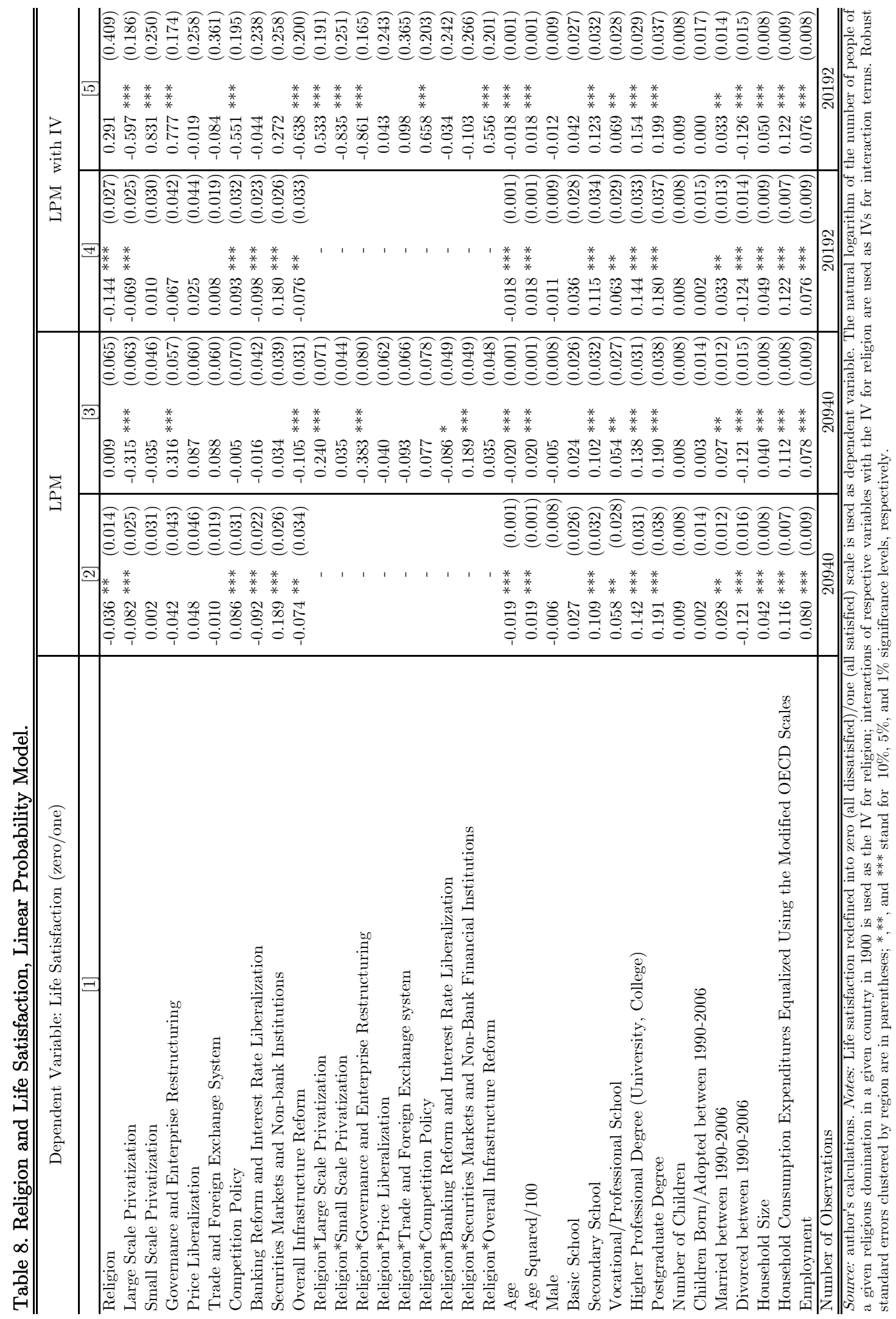




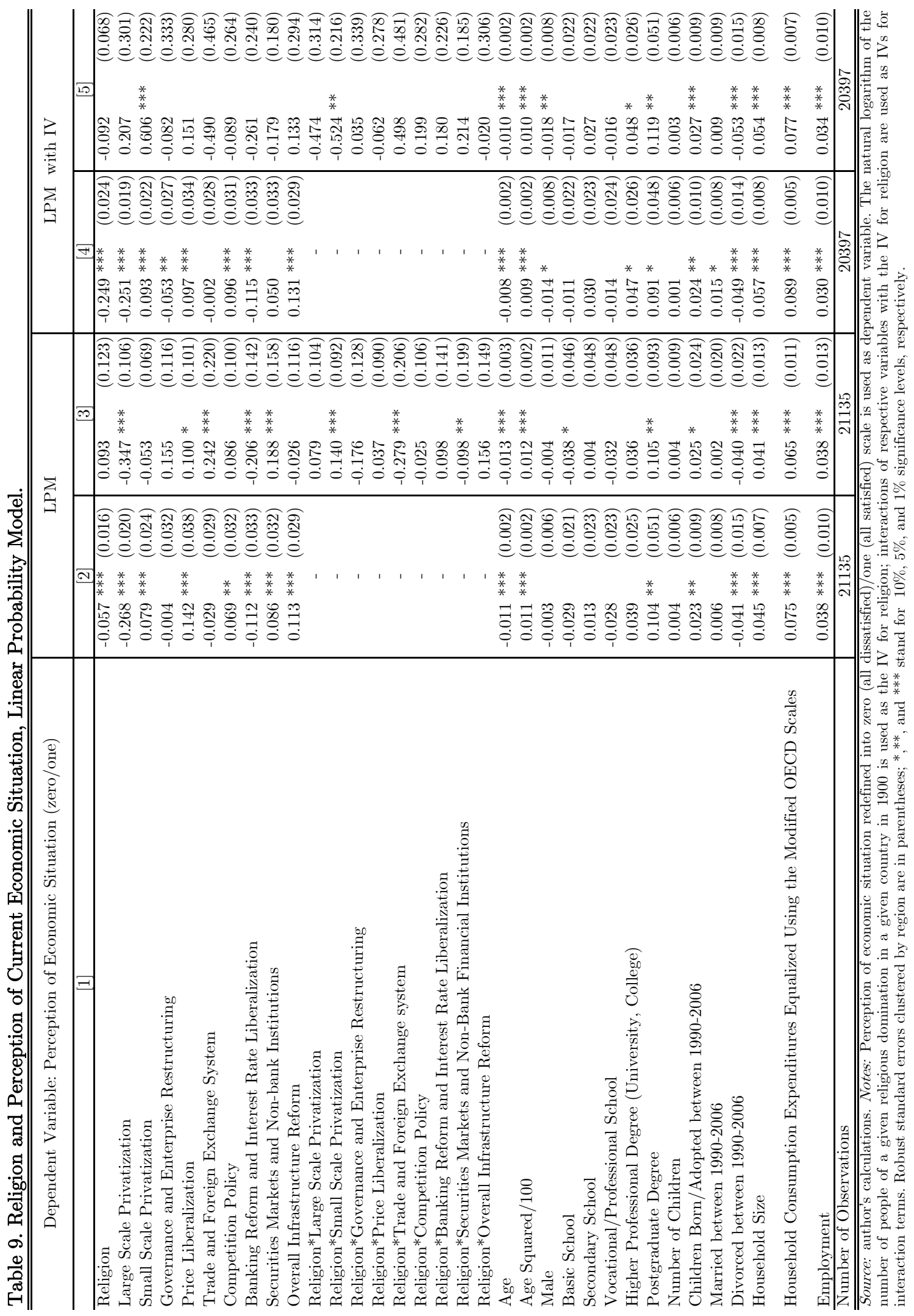




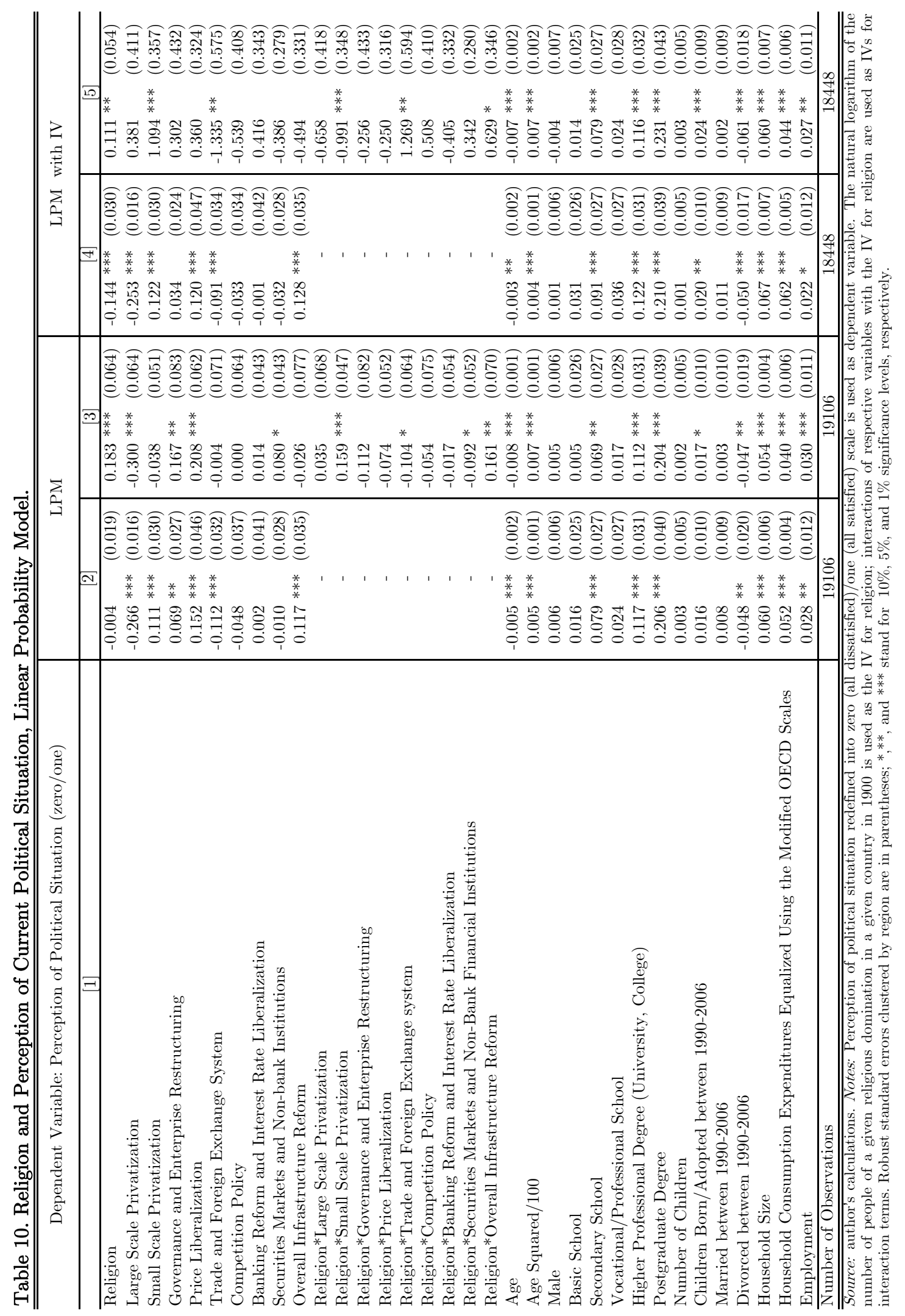




\section{A3. Supplementary Tables}

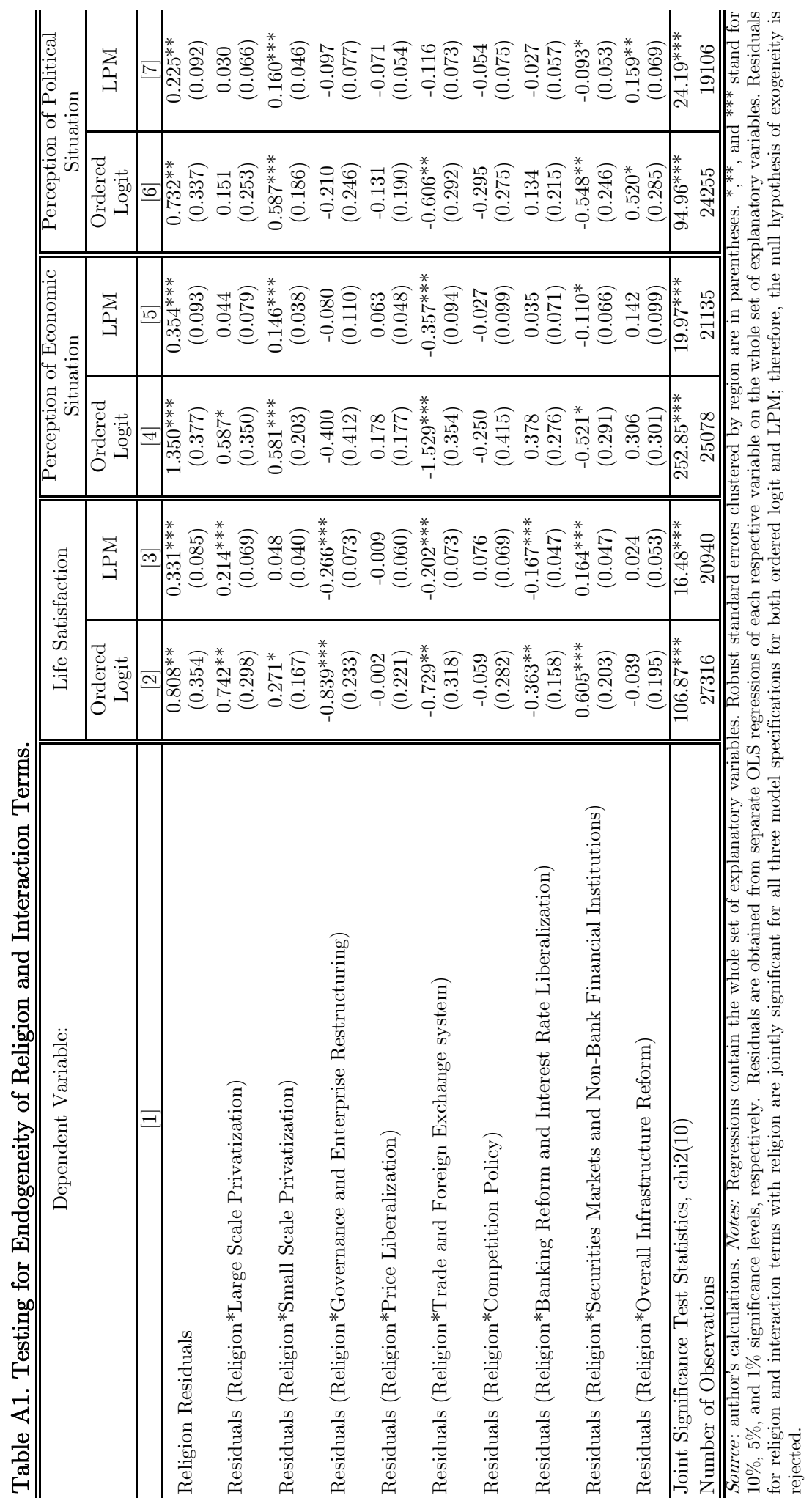


Table A2. Testing for Weak IV.

\begin{tabular}{l|c|c}
\hline \multicolumn{1}{c|}{ First Stage Dependent Variable } & $\begin{array}{c}\text { First Stage F-statistics } \\
\text { for Joint Significance of } \\
\text { Instruments }\end{array}$ & $\begin{array}{c}\text { Partial Correlation of } \\
\text { Endogenous Variable } \\
\text { with its IV }\end{array}$ \\
\hline \multicolumn{1}{c|}{$[1]$} & {$[2]$} & {$[3]$} \\
\hline Religion & $2458.29^{* * *}(0.000)$ & 0.554 \\
Religion*Large Scale Privatization & $2380.81^{* * *}(0.000)$ & 0.732 \\
Religion*Small Scale Privatization & $2230.73^{* * *}(0.000)$ & 0.769 \\
Religion*Governance and Enterprise Restructuring & $2569.69^{* * *}(0.000)$ & 0.797 \\
Religion*Price Liberalization & $2211.39^{* * *}(0.000)$ & 0.732 \\
Religion*Trade and Foreign Exchange system & $2283.63^{* * *}(0.000)$ & 0.706 \\
Religion*Competition Policy & $2644.81^{* * *}(0.000)$ & 0.818 \\
Religion*Banking Reform and Interest Rate Liberalization & $2433.43^{* * *}(0.000)$ & 0.720 \\
Religion*Securities Markets and Non-Bank Financial Institutions & $2368.71^{* * *}(0.000)$ & 0.790 \\
Religion*Overall Infrastructure Reform & $2308.03^{* * *}(0.000)$ & 0.739 \\
\hline \hline
\end{tabular}

Source: author's calculations. Notes: each first stage regression contains the whole set of instrumental variables (one for religion and 9 for interaction terms with religion) and explanatory variables. The natural logarithm of the number of people of a given religious domination in a given country in 1900 is used as the IV for religion; interactions of respective variables with the IV for religion are used as IVs for interaction terms. P-values are in parentheses. *,**, and *** stand for $10 \%, 5 \%$, and $1 \%$ significance levels, respectively. Weak Instrument Test proposed by Stock and Yogo (2005) has been used. First stage F-statistics are significant for all 10 first stages; therefore, the null hypothesis of the weak IV is rejected. Partial correlations also suggest a nonzero correlation between the proposed instrument and respective endogenous variable.

Table A3. Life Satisfaction, Predicted Probabilities of Giving Different Replies.

\begin{tabular}{|c|c|c|c|c|}
\hline & Mean & Std. Err. & \multicolumn{2}{|c|}{$[95 \%$ Conf. Interval] } \\
\hline \multicolumn{5}{|c|}{ Religion and All Other Variables at Mean } \\
\hline$\overline{\operatorname{Pr}(\text { strongly disagree) }}$ & 0.090 & 0.005 & 0.081 & 0.100 \\
\hline $\operatorname{Pr}($ disagree $)$ & 0.220 & 0.007 & 0.208 & 0.233 \\
\hline $\operatorname{Pr}($ neither disagree nor agree $)$ & 0.254 & 0.005 & 0.243 & 0.265 \\
\hline $\operatorname{Pr}($ agree $)$ & 0.366 & 0.009 & 0.349 & 0.384 \\
\hline $\operatorname{Pr}($ strongly agree $)$ & 0.070 & 0.002 & 0.066 & 0.075 \\
\hline \multicolumn{5}{|c|}{ Religion at Min, All Other Variables at Mean } \\
\hline$\overline{\operatorname{Pr}(\text { strongly disagree) }}$ & 0.101 & 0.014 & 0.075 & 0.132 \\
\hline $\operatorname{Pr}($ disagree $)$ & 0.235 & 0.021 & 0.195 & 0.278 \\
\hline $\operatorname{Pr}($ neither disagree nor agree $)$ & 0.256 & 0.007 & 0.238 & 0.269 \\
\hline $\operatorname{Pr}($ agree $)$ & 0.345 & 0.029 & 0.286 & 0.401 \\
\hline $\operatorname{Pr}($ strongly agree $)$ & 0.064 & 0.011 & 0.044 & 0.087 \\
\hline \multicolumn{5}{|c|}{ Religion at Max, All Other Variables at Mean } \\
\hline$\overline{\operatorname{Pr}(\text { strongly disagree) }}$ & 0.081 & 0.007 & 0.068 & 0.095 \\
\hline $\operatorname{Pr}($ disagree $)$ & 0.205 & 0.011 & 0.183 & 0.227 \\
\hline $\operatorname{Pr}($ neither disagree nor agree) & 0.249 & 0.005 & 0.240 & 0.259 \\
\hline $\operatorname{Pr}($ agree $)$ & 0.387 & 0.015 & 0.358 & 0.416 \\
\hline $\operatorname{Pr}($ strongly agree $)$ & 0.078 & 0.004 & 0.070 & 0.087 \\
\hline
\end{tabular}

Source: author's calculations. Notes: Simulations are performed using CLARIFY software. First, the model is estimated by ordered logit, controlling for endogeneity and 1000 sets of simulated coefficients are drawn. Predicted probabilities of different replies are calculated based on the sets of simulated coefficients and different values of religion and means of other explanatory variables. 
Table A4. Perceptions of Economic Situation, Predicted Probabilities of Giving Different Replies.

\begin{tabular}{|c|c|c|c|c|}
\hline & Mean & Std. Err. & \multicolumn{2}{|c|}{$[95 \%$ Conf. Interval $]$} \\
\hline \multicolumn{5}{|c|}{ Religion and All Other Variables at Mean } \\
\hline $\operatorname{Pr}($ strongly disagree) & 0.174 & 0.008 & 0.157 & 0.190 \\
\hline $\operatorname{Pr}($ disagree $)$ & 0.321 & 0.007 & 0.307 & 0.334 \\
\hline $\operatorname{Pr}($ neither disagree nor agree) & 0.177 & 0.005 & 0.167 & 0.188 \\
\hline $\operatorname{Pr}($ agree $)$ & 0.267 & 0.008 & 0.251 & 0.283 \\
\hline $\operatorname{Pr}($ strongly agree $)$ & 0.061 & 0.003 & 0.057 & 0.066 \\
\hline \multicolumn{5}{|c|}{ Religion at Min, All Other Variables at Mean } \\
\hline $\operatorname{Pr}$ (strongly disagree) & 0.184 & 0.029 & 0.135 & 0.249 \\
\hline $\operatorname{Pr}($ disagree $)$ & 0.325 & 0.022 & 0.280 & 0.365 \\
\hline $\operatorname{Pr}($ neither disagree nor agree) & 0.174 & 0.007 & 0.158 & 0.184 \\
\hline $\operatorname{Pr}($ agree $)$ & 0.258 & 0.034 & 0.189 & 0.324 \\
\hline $\operatorname{Pr}($ strongly agree $)$ & 0.059 & 0.012 & 0.039 & 0.085 \\
\hline \multicolumn{5}{|c|}{ Religion at Max, All Other Variables at Mean } \\
\hline $\operatorname{Pr}($ strongly disagree) & 0.158 & 0.010 & 0.138 & 0.179 \\
\hline $\operatorname{Pr}($ disagree $)$ & 0.307 & 0.008 & 0.293 & 0.322 \\
\hline $\operatorname{Pr}($ neither disagree nor agree) & 0.180 & 0.006 & 0.168 & 0.191 \\
\hline $\operatorname{Pr}($ agree $)$ & 0.286 & 0.010 & 0.269 & 0.306 \\
\hline $\operatorname{Pr}($ strongly agree) & 0.068 & 0.004 & 0.061 & 0.077 \\
\hline
\end{tabular}

Source: author's calculations. Notes: Simulations are performed using CLARIFY software. First, the model is estimated by ordered logit, controlling for endogeneity and 1000 sets of simulated coefficients are drawn. Predicted probabilities of different replies are calculated based on the sets of simulated coefficients and different values of religion and means of other explanatory variables.

Table A5. Perceptions of Political Situation, Predicted Probabilities of Giving Different Replies.

\begin{tabular}{|c|c|c|c|c|}
\hline & Mean & Std. Err. & \multicolumn{2}{|c|}{ [95\% Conf. Interval] } \\
\hline \multicolumn{5}{|c|}{ Religion and All Other Variables at Mean } \\
\hline $\operatorname{Pr}$ (strongly disagree) & 0.160 & 0.008 & 0.145 & 0.175 \\
\hline $\operatorname{Pr}($ disagree $)$ & 0.272 & 0.009 & 0.254 & 0.288 \\
\hline $\operatorname{Pr}($ neither disagree nor agree) & 0.231 & 0.006 & 0.219 & 0.241 \\
\hline $\operatorname{Pr}($ agree $)$ & 0.274 & 0.008 & 0.260 & 0.289 \\
\hline $\operatorname{Pr}$ (strongly agree) & 0.064 & 0.003 & 0.058 & 0.070 \\
\hline \multicolumn{5}{|c|}{ Religion at Min, All Other Variables at Mean } \\
\hline$\overline{\operatorname{Pr}(\text { strongly disagree })}$ & 0.199 & 0.017 & 0.168 & 0.232 \\
\hline $\operatorname{Pr}($ disagree $)$ & 0.298 & 0.015 & 0.269 & 0.326 \\
\hline $\operatorname{Pr}($ neither disagree nor agree) & 0.221 & 0.008 & 0.206 & 0.234 \\
\hline $\operatorname{Pr}($ agree $)$ & 0.232 & 0.018 & 0.197 & 0.270 \\
\hline $\operatorname{Pr}($ strongly agree) & 0.050 & 0.006 & 0.039 & 0.062 \\
\hline \multicolumn{5}{|c|}{ Religion at Max, All Other Variables at Mean } \\
\hline$\overline{\operatorname{Pr}(\text { strongly disagree })}$ & 0.149 & 0.010 & 0.130 & 0.170 \\
\hline $\operatorname{Pr}($ disagree $)$ & 0.263 & 0.010 & 0.243 & 0.280 \\
\hline $\operatorname{Pr}($ neither disagree nor agree) & 0.232 & 0.006 & 0.220 & 0.242 \\
\hline $\operatorname{Pr}($ agree $)$ & 0.288 & 0.010 & 0.268 & 0.310 \\
\hline $\operatorname{Pr}$ (strongly agree) & 0.069 & 0.004 & 0.061 & 0.077 \\
\hline
\end{tabular}

Source: author's calculations. Notes: Simulations are performed using CLARIFY software. First, the model is estimated by ordered logit, controlling for endogeneity and 1000 sets of simulated coefficients are drawn. Predicted probabilities of different replies are calculated based on the sets of simulated coefficients and different values of religion and means of other explanatory variables. 


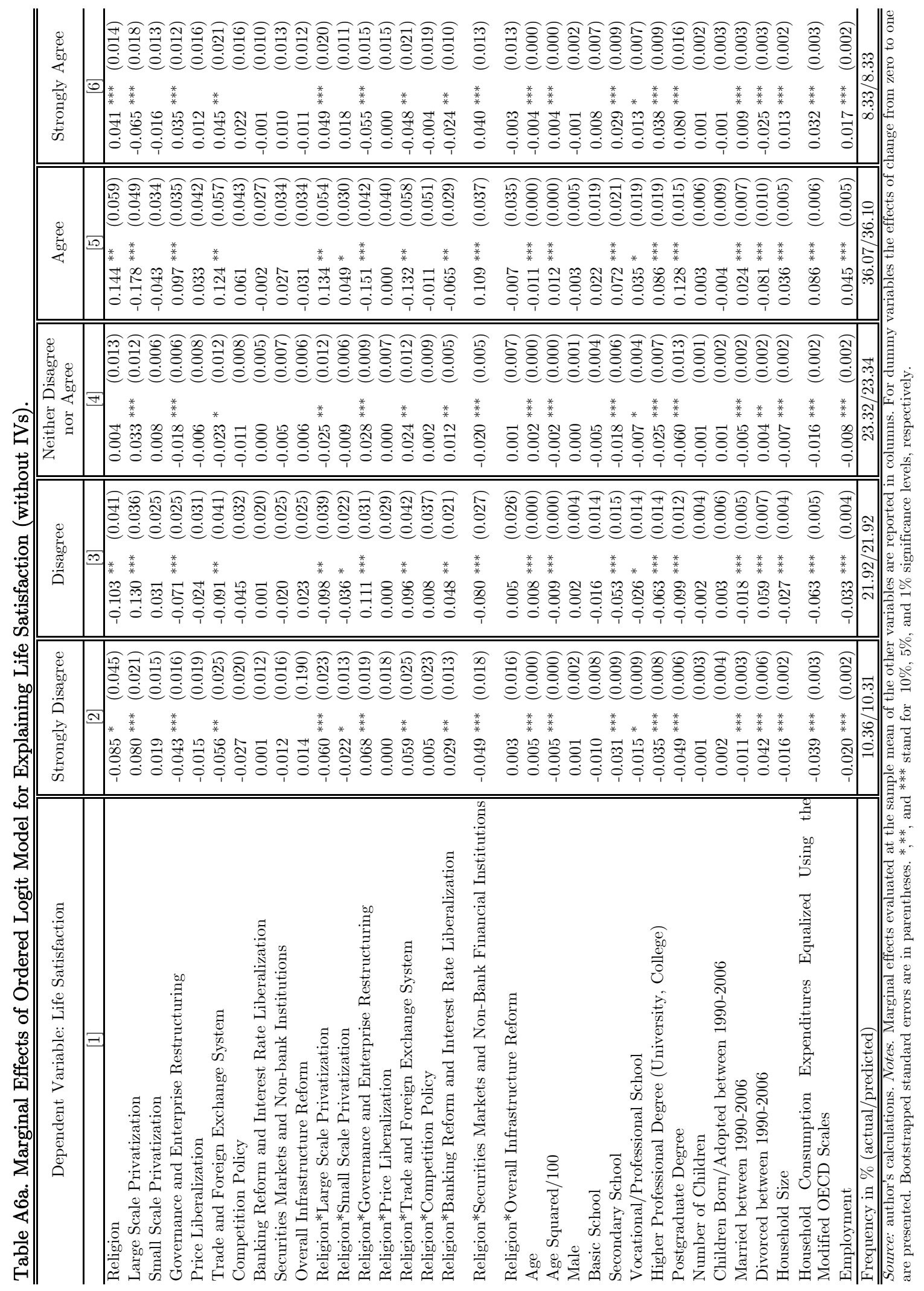




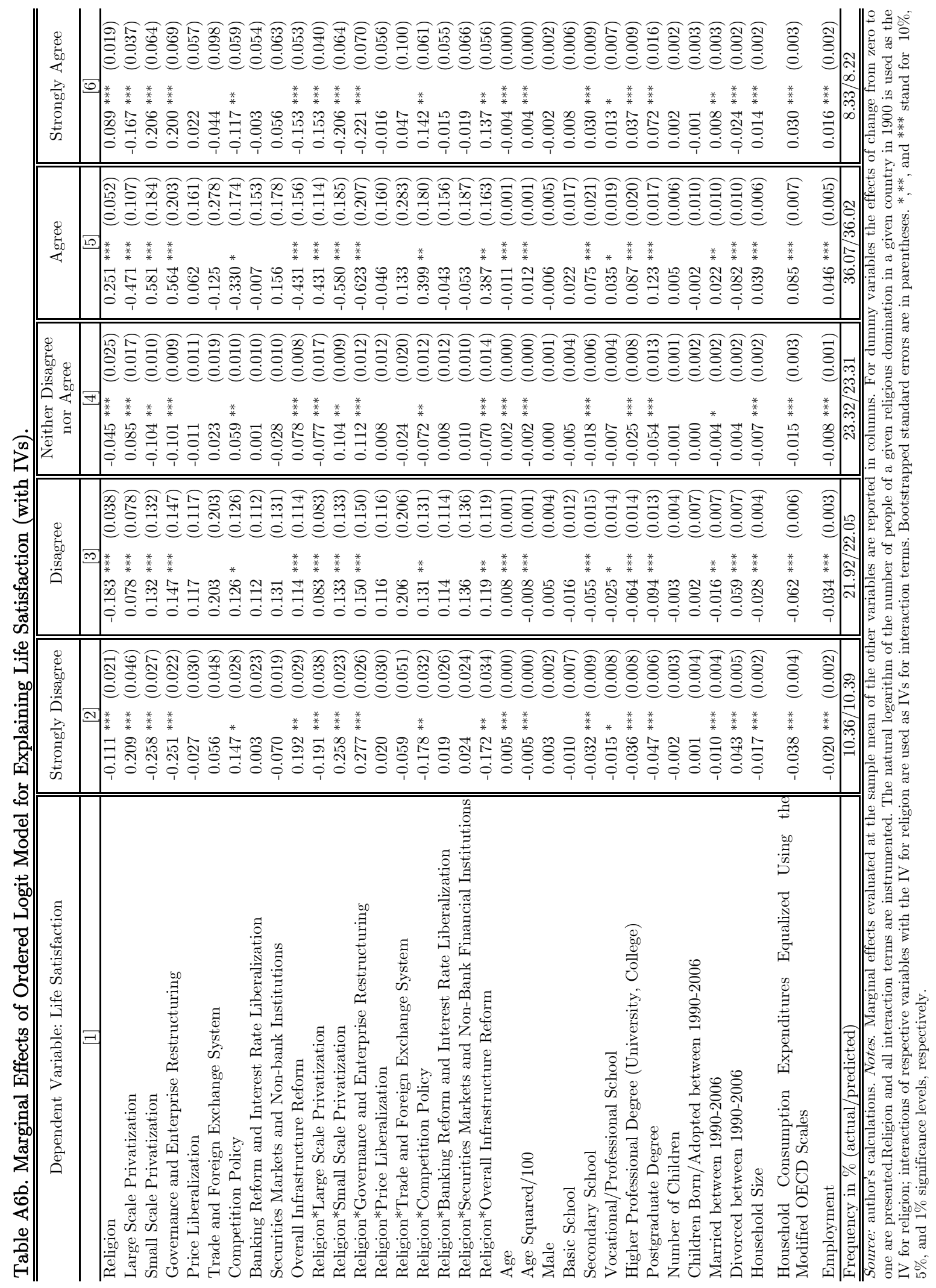




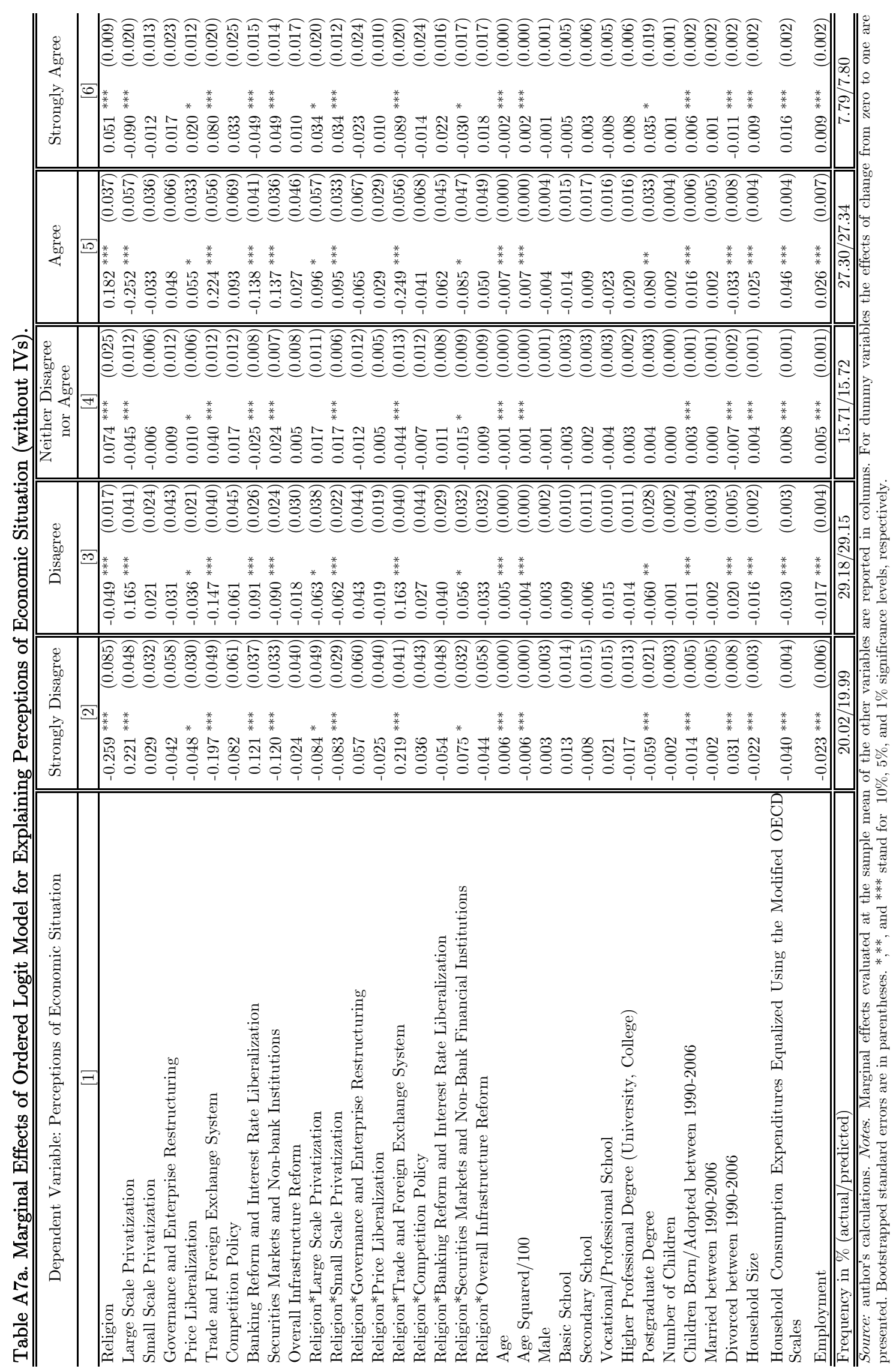




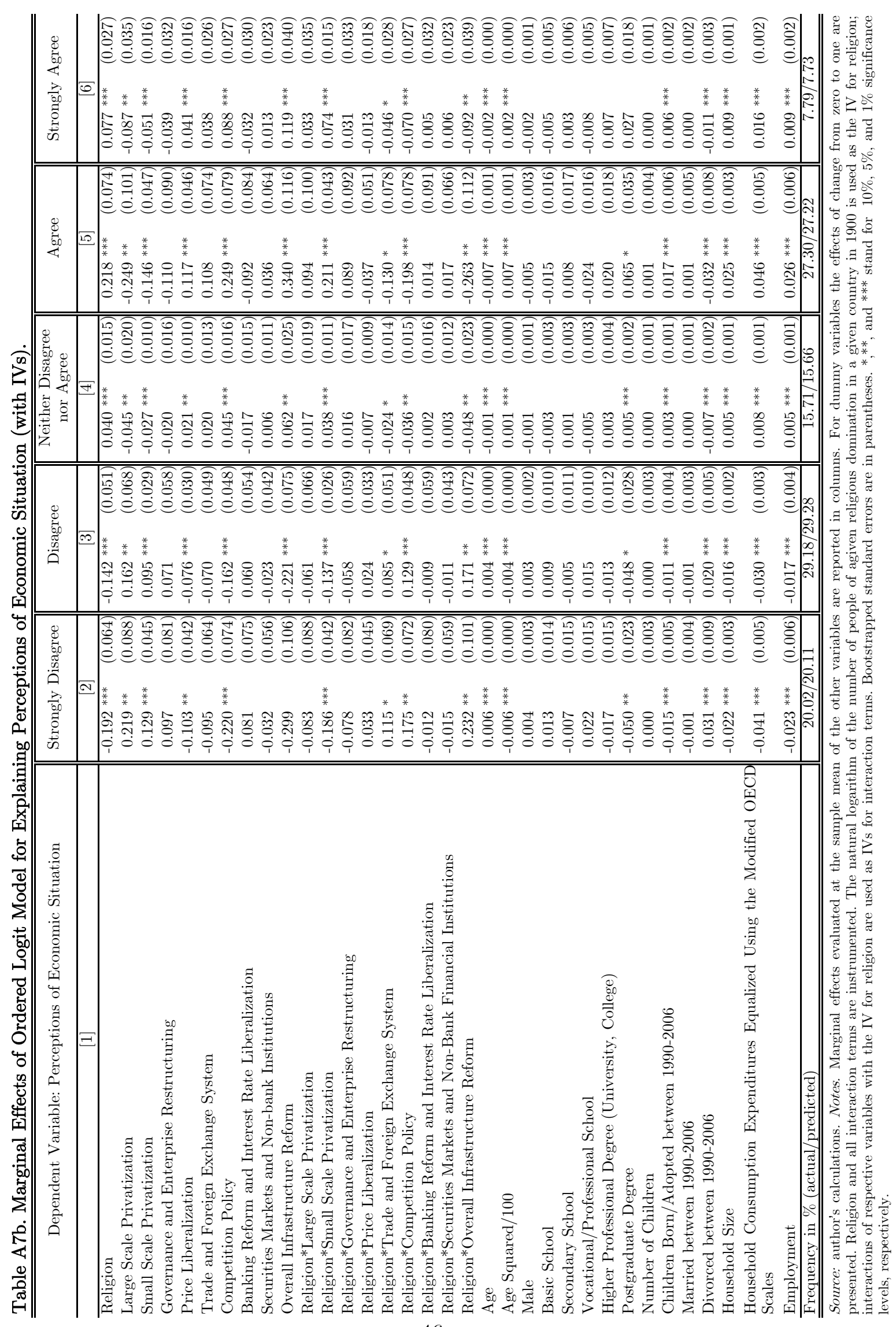




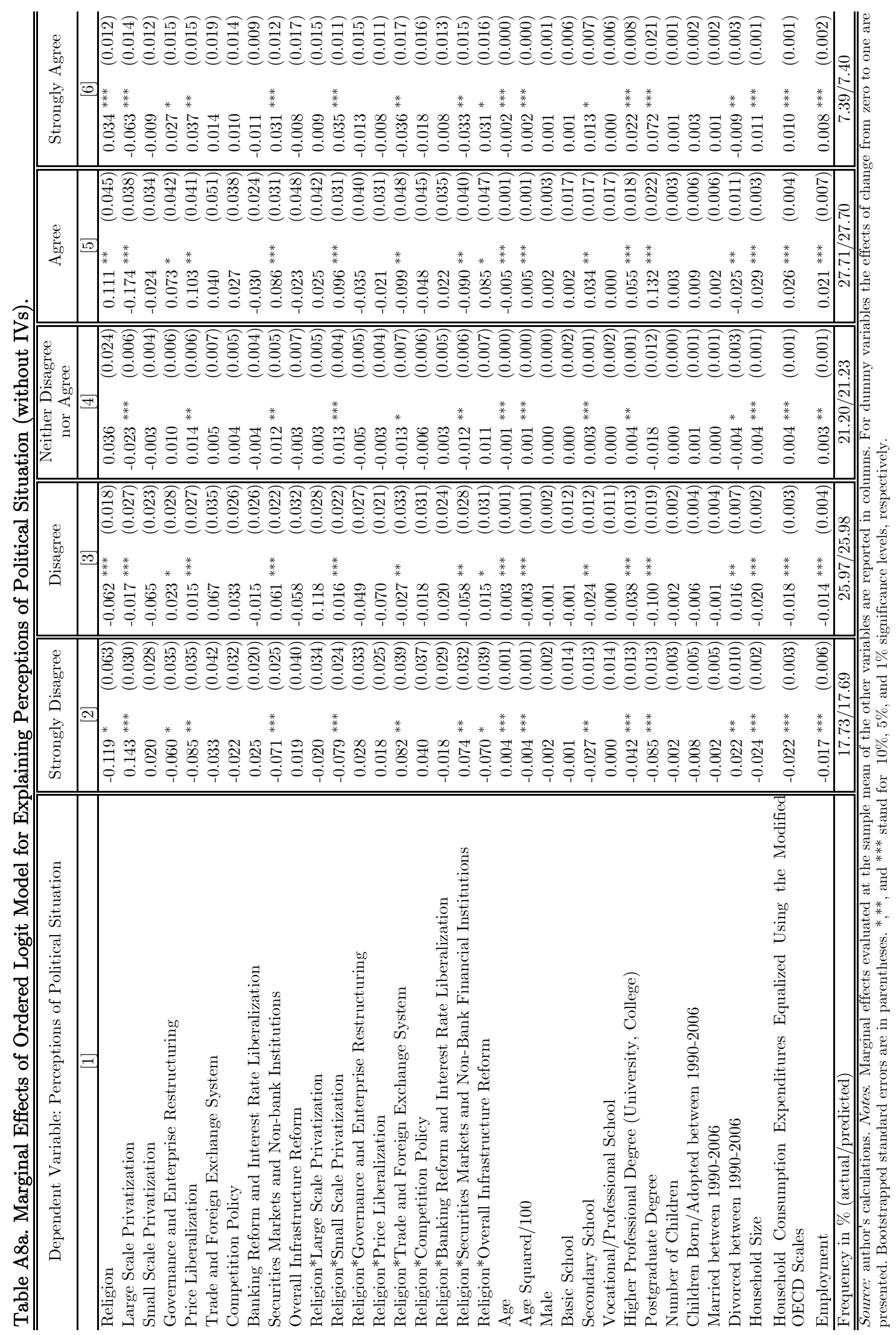




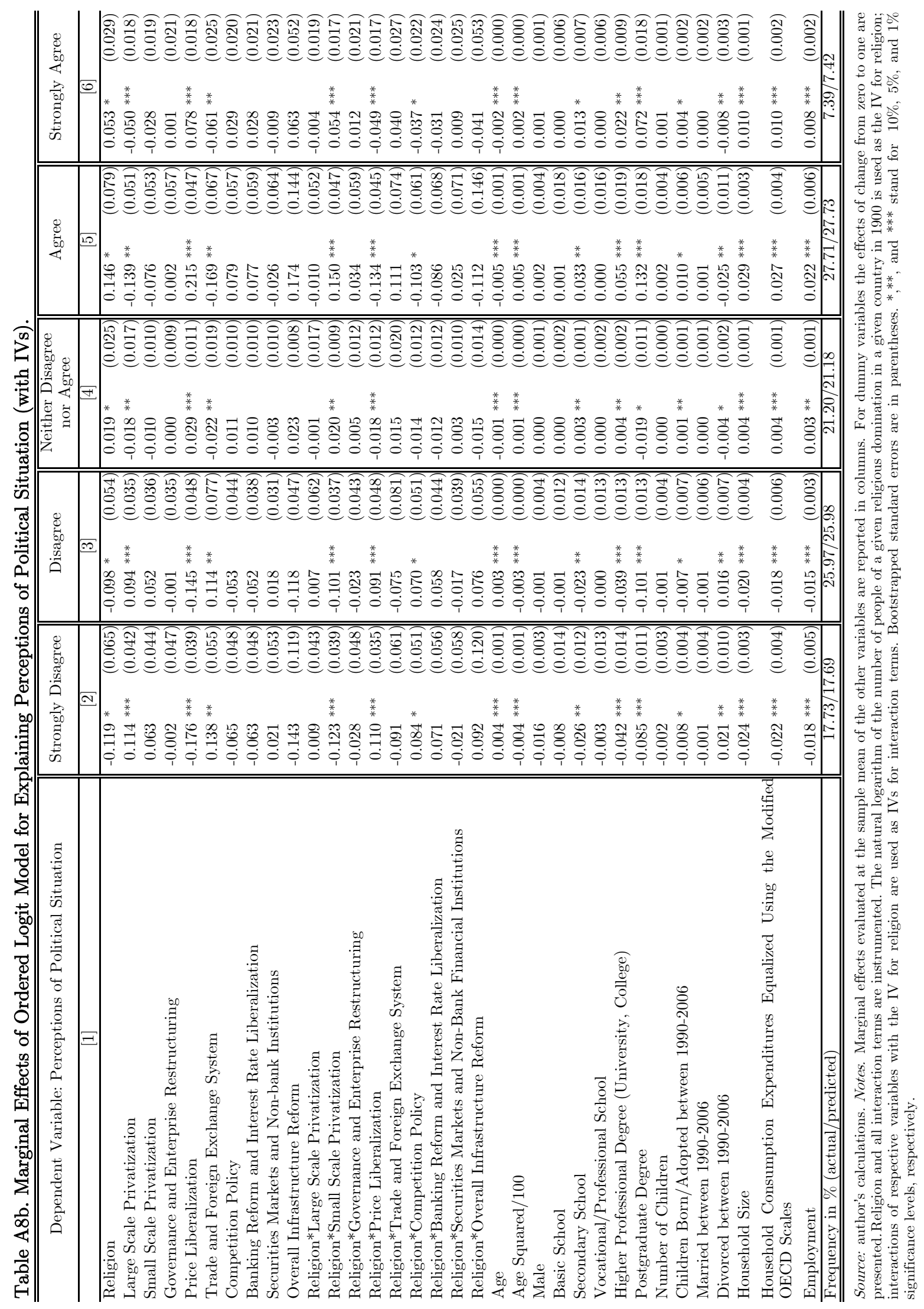




\section{Working Paper Series}

ISSN 1211-3298

Registration No. (Ministry of Culture): E 19443

Individual researchers, as well as the on-line and printed versions of the CERGE-EI Working Papers (including their dissemination) were supported from the European Structural Fund (within the Operational Programme Prague Adaptability), the budget of the City of Prague, the Czech Republic's state budget and the following institutional grants:

- Center of Advanced Political Economy Research [Centrum pro pokročilá politickoekonomická studia], No. LC542, (2005-2010);

- Economic Aspects of EU and EMU Entry [Ekonomické aspekty vstupu do Evropské unie a Evropské měnové unie], No. AVOZ70850503, (2005-2010);

- Economic Impact of European Integration on the Czech Republic [Ekonomické dopady evropské integrace na ČR], No. MSM0021620846, (2005-2011);

Specific research support and/or other grants the researchers/publications benefited from are acknowledged at the beginning of the Paper.

\section{(c) Olga Popova, 2010}

All rights reserved. No part of this publication may be reproduced, stored in a retrieval system or transmitted in any form or by any means, electronic, mechanical or photocopying, recording, or otherwise without the prior permission of the publisher.

Published by

Charles University in Prague, Center for Economic Research and Graduate Education (CERGE) and

Economics Institute ASCR, v. v. i. (EI)

CERGE-El, Politických vězňů 7, 11121 Prague 1, tel.: +420 224005 153, Czech Republic.

Printed by CERGE-EI, Prague

Subscription: CERGE-EI homepage: http://www.cerge-ei.cz

Phone: + 420224005153

Email: office@cerge-ei.cz

Web: http://www.cerge-ei.cz

Editor: Michal Kejak

Editorial board: Jan Kmenta, Randall Filer, Petr Zemčík

The paper is available online at http://www.cerge-ei.cz/publications/working_papers/.

ISBN 978-80-7343-224-9 (Univerzita Karlova. Centrum pro ekonomický výzkum a doktorské studium)

ISBN 978-80-7344-214-9 (Národohospodářský ústav AV ČR, v. v. i.) 
CERGE-EI

P.O.BOX 882

Politických vězňů 7

11121 Praha 1

Czech Republic http://www.cerge-ei.cz 